\title{
Buckling Curves for Cold-Formed Stainless-Steel Columns and Beams
}

\author{
Itsaso Arrayago ${ }^{1}$ and Kim J. R. Rasmussen ${ }^{2}$ \\ ${ }^{1}$ Itsaso Arrayago, Ph.D. (Corresponding author). Marie Skłodowska-Curie Individual Fellow, \\ Department of Civil and Environmental Engineering, Universitat Politècnica de Catalunya, \\ Barcelona 08034, Spain. ORCID: http://orcid.org/0000-0002-0054-9322. Email: \\ itsaso.arrayago@upc.edu \\ ${ }^{2}$ Kim J. R. Rasmussen. M.ASCE, Ph.D., D.Eng. Professor of Civil Engineering, School of Civil \\ Engineering, The University of Sydney, 2006 NSW, Australia. ORCID: https://orcid.org/0000- \\ 0002-8649-9257. Email: kim.rasmussen@sydney.edu.au
}

\begin{abstract}
This paper summarises the background information and methodology used to derive a set of buckling curves proposed for cold-formed stainless steel columns and beams, incorporated in the recently revised SEI/ASCE 8-21 Specification. The study is based on experimental and numerical data collected from the literature on cold-formed stainless steel columns and beams featuring ASTM grades 304, 2101, 430, 404 and 443. Since most of the investigated specimens exhibited slender cross-sections, both the Effective Width Method (EWM) and the Direct Strength Method (DSM) are considered to account for the effect of interaction between global and local buckling on member strength. Buckling curves for flexural buckling and lateraltorsional buckling codified in current international standards are assessed based on the SEI/ASCE 8 reliability requirements, and new curves are derived accordingly. The proposed new buckling curves include expressions to account for the post-yielding capacity of stainless steel columns and the inelastic buckling resistance of cold-formed stainless steel beams. In addition, a new local buckling strength curve for members in flexure is proposed in the format of the DSM and shown to provide equivalent design resistances to the EWM.
\end{abstract}

\section{KEYWORDS}

SEI/ASCE 8; beams; columns; cold-formed; Direct Strength Method; flexural buckling; lateral-torsional buckling; stainless steel 


\section{Buckling curves for cold-formed stainless steel columns and beams}

Itsaso Arrayago $^{\mathrm{a}^{*}}$ and Kim J.R. Rasmussen ${ }^{\mathrm{b}}$

${ }^{a}$ Dept. of Civil and Environmental Engineering, Universitat Politècnica de Catalunya, Spain

${ }^{b}$ School of Civil Engineering, The University of Sydney, Australia

\section{INTRODUCTION}

Cold-formed stainless steel members are commonly used in structural and architectural applications due to the high strength- and stiffness-to-weight ratios offered by cold-formed cross-sections combined with the corrosion resistance and durability provided by stainless steel alloys (Baddoo 2008; Gardner 2019). The behaviour of stainless steel structures has been the subject of numerous experimental and numerical research studies over the last decades, which have led to the development of dedicated design rules and standards for stainless steel structures worldwide. The first standard on structural stainless steel, the AISI Specification for the Design of Light Gage Cold-Formed Stainless Steel Structural Members (AISI 1968), was published in 1968 and superseded by the SEI/ASCE 8-90 Specification (SEI/ASCE 8 Committee 1990), the first edition of the European Design Manual for Structural Stainless Steel (Euro Inox 1994), the first European code ENV 1993-1-4 (CEN 1996) and the first AS/NZS 4673:2001 Specification (AS/NZS 2001). Since then, international standards have been regularly revised and updated to cover new material grades and incorporate the advances made by the research community in developing design provisions for different loading types and failure modes. All these standards are currently being updated and the revised versions have been published in the last few years or are due to be published soon, including the 2017 edition of the European Design Manual (SCI 2017), the upcoming version of the prEN 1993-1-4 (CEN 2020) standard and the revised version of the AISC 370 Specification for fabricated stainless steel structures (AISC 2021), which has recently been sent for public review.

In the same line of work, the final version of the updated SEI/ASCE 8-02 standard, the SEI/ASCE 8-21 Specification (SEI/ASCE 8 Committee 2021), is expected to be published in 2021. Although the upcoming SEI/ASCE 8-21 Specification has undergone extensive revision throughout the different chapters including design provisions for different component and loading types, this paper focuses on Chapters 5 and 6 featuring specifications for cold-formed stainless steel columns and beams, respectively. Design provisions for the overall buckling behaviour of stainless steel columns and beams (i.e. flexural buckling and lateral-torsional 
buckling) included in the superseded 2002 version of the SEI/ASCE 8-02 Specification were based on the tangent modulus approach, and the interaction between local and overall buckling was accounted for through the traditional Effective Width Method. However, with the aim of aligning the updated SEI/ASCE 8-21 Specification (SEI/ASCE 8 Committee 2021) with other specifications for the design of cold-formed structural steel AISI S100-16 (AISI 2016) and stainless steel members AISC 370-21 (AISC 2021), the SEI/ASCE 8 Committee decided to adopt the explicit approach for the design of cold-formed stainless steel columns and beams using the concept of buckling curves. The revised SEI/ASCE 8-21 Specification has also adopted the Direct Strength Method (DSM) as the primary approach to account for local buckling effects in the main body of the Specification, as per in AISI S100-16 (AISI 2016), and has re-allocated the traditional Effective Width Method to one of its appendices.

These fundamental changes in the design approach made it necessary to develop suitable explicit buckling curves for cold-formed stainless steel members and to derive specific DSM strength curves for the treatment of local buckling effects. This paper presents the background information and methodology used in the calibration of the buckling curves proposed for cold-formed stainless steel columns and beams incorporated in the revised SEI/ASCE 8-21 Specification (SEI/ASCE 8 Committee 2021). Buckling curves available in equivalent stainless steel standards are evaluated first for each member type (i.e. columns and beams), and new curves are derived when deemed necessary based on comprehensive reliability analyses. The proposed new buckling curves also incorporate the effect of the post-yielding capacity of stainless steel columns and the inelastic buckling resistance of cold-formed stainless steel beams, and are summarized in the last section of the paper.

\section{COLD-FORMED STAINLESS STEEL MEMBERS IN COMPRESSION}

The behaviour of cold-formed stainless steel members under compressive loads has been extensively investigated over the last decades through comprehensive experimental and numerical studies. Although the majority of these studies focused on the behaviour of cold-formed rectangular or circular hollow sections (Rasmussen and Hancock 1993a; Huang and Young 2013: Arrayago et al. 2016; Zhao et al. 2016, among others), relevant studies on cold-formed open sections can also be found in the literature. The first research works on the response of cold-formed stainless steel columns with press-braked back-to-back channel sections by Johnson and Winter (1966) were followed by tests on stainless steel columns with lipped channel 
sections by Coetzee et al. (1990), on small lipped channel sections by Rhodes et al. (2000), and stub column tests on press-braked angles, lipped channel and plain channel sections by Kuwamura (2003). More recently, the interactions of global flexural buckling with local (Becque 2008; Becque et al. 2008; Becque and Rasmussen 2009a, 2009b, 2009c, 2009d; Fan et al. 2014) and distortional (Lecce and Rasmussen 2006) buckling modes were investigated for cold-formed stainless steel I-section and lipped channel sections, as well as for plain channels (Dobrić et al. 2017; Dobrić and Rossi 2020). These studies have improved the understanding of the behaviour of cold-formed stainless steel columns and have considerably extended the pool of available experimental and numerical databases since the design provisions codified in the current SEI/ASCE 8-02 Specification (SEI/ASCE 8 Committee 2002) were developed.

This section presents the derivation of the new flexural buckling curves for cold-formed stainless steel columns included in the revised SEI/ASCE 8-21 Specification (SEI/ASCE 8 Committee 2021) using existing experimental and numerical data. These buckling curves follow design equations included in other international standards for stainless steel columns and have been proposed based on accuracy and reliability considerations. Finally, an approach to account for the post-yielding capacity of stainless steel columns is proposed.

\section{FLEXURAL BUCKLING CURVES FOR COLD-FORMED STAINLESS STEEL COLUMNS}

In explicit column design approaches, the nominal axial strength $P_{n e}$ of fully effective columns can be calculated from Eq. (1), where $A_{g}$ is the cross-section gross area and $F_{n}$ is the global flexural buckling stress, which is calculated using appropriate flexural buckling curves for stainless steel members, the calibration of which is investigated in this paper.

$$
P_{n e}=A_{g} F_{n}
$$

In the recent revision of the AISC 370-21 Specification (AISC 2021), new buckling curves were proposed for stainless steel columns with rectangular and round Hollow Structural Sections (HSS), as well as for welded I-sections, as shown in Eqs. (2a) to (2c), where $\lambda_{c}$ is the column slenderness calculated from Eq. (3) through the yield stress $F_{y}$ and the elastic flexural buckling stress $F_{c r e}$. Different buckling curves (denoted as Curve 0, Curve 1 and Curve 2 in this paper) have been provided in the revised AISC 370-21 Specification (AISC 2021) for different cross-section shapes and buckling axes through the $\alpha, \beta_{0}, \beta_{1}, \beta_{2}$ and $\lambda_{\text {lim }}$ 
parameters summarized in Table 1. However, no revised buckling curves have been proposed for cold-formed open sections since these cross-section types are outside the scope of the AISC 370-21 Specification (AISC 2021).

$$
\begin{array}{ll}
\text { For } \lambda_{c} \leq \beta_{0} & F_{n}=F_{y} \\
\text { For } \beta_{0}<\lambda_{c} \leq \lambda_{\text {lim }} & F_{n}=1.2\left(\beta_{1}{ }^{\left.\left(\lambda_{c}\right)^{\alpha}\right)}\right) F_{y} \\
\text { For } \lambda_{c}>\lambda_{\text {lim }} & F_{n}=\beta_{2} F_{\text {cre }} \\
& \lambda_{c}=\sqrt{F_{y} / F_{\text {cre }}}
\end{array}
$$

Current European standards EN 1993-1-4 (CEN 2015) and design manuals (SCI 2017) provide slightly different buckling curves for cold-formed stainless steel columns to those proposed for the AISC 370-21 Specification (AISC 2021). The buckling curves codified in the current EN 1993-1-4 (CEN 2015) standard have been recently revised and included in the fourth edition of the Design Manual for Stainless Steel Structures (SCI 2017) and in the upcoming version of prEN 1993-1-4 (CEN 2020). According to the Design Manual (SCI 2017) and prEN 1993-1-4 (CEN 2020), the European buckling curve $c$ with a slenderness plateau of 0.2 should be adopted for cold-formed lipped channels, round HSS and ferritic stainless steel rectangular HSS, while buckling curve $c$ with a slenderness plateau of 0.3 is prescribed for austenitic and duplex alloy rectangular HSS, and buckling curve $d$ with a slenderness plateau of 0.2 is codified for coldformed angles and channels. With the aim of achieving consistency among US design specifications for stainless steel structures, the SEI/ASCE 8 Committee decided to derive a set of buckling curves for the revised SEI/ASCE 8-21 Specification (SEI/ASCE 8 Committee 2021) by using the same equations as those defined in AISC 370-21 (AISC 2021) while calibrating new $\alpha, \beta_{0}, \beta_{1}, \beta_{2}$ and $\lambda_{\text {lim }}$ parameters suitable for cold-formed stainless steel columns, including I-section, lipped channel section and plain channel section columns, as presented in this paper.

In contrast to hot-rolled and welded stainless steel sections, cold-formed columns usually comprise crosssections with high local slenderness values and generally fail by interaction of overall and local buckling modes. As mentioned previously, the revised SEI/ASCE 8-21 Specification (SEI/ASCE 8 Committee 2021) has adopted the Direct Strength Method (DSM) to incorporate the effect of interaction of flexural buckling and local buckling at cross-section level to be aligned with the AISI S100-16 Specification (AISI 2016) for 
carbon steel, but requires different strength curves to be calibrated to reflect the specific characteristics of stainless steel sections. Since the DSM local buckling strength curve proposed by Becque et al. (2008) for compression, which is given in Eq. (4), has been shown to provide accurate results for stainless steel columns (Becque et al. 2008, Arrayago et al. 2017a, 2017b), it was decided to adopt this approach in the SEI/ASCE 821 Specification (SEI/ASCE 8 Committee 2021) for cold-formed stainless steel cross-sections and members subjected to compression. In Eq. (4), $P_{n l}$ is the nominal axial strength of columns including the interaction with local buckling, $P_{n e}$ is the column resistance of the fully effective cross-section, as per Eq. (1), and $\lambda_{l}$ is the local slenderness of the cross-section, which can be determined from Eq. (5), where $P_{c r, l}$ and $F_{c r, l}$ are the critical elastic local column buckling load and stress, respectively.

$$
\begin{gathered}
\frac{P_{n l}}{P_{n e}}=\left\{\begin{array}{cc}
1.0 & \text { for } \lambda_{l} \leq 0.55 \\
\frac{0.95}{\lambda_{l}}-\frac{0.22}{\lambda_{l}^{2}} & \text { for } \lambda_{l}>0.55
\end{array}\right. \\
\lambda_{l}=\sqrt{P_{n e} / P_{c r, l}}=\sqrt{F_{n} / F_{c r, l}}
\end{gathered}
$$

It is important to note that plain channel columns with slender cross-sections are subject to a shift in the centroid of the cross-section under uniform compression, resulting from an asymmetric redistribution of longitudinal stresses due to local buckling. When these columns are pin-ended, the shift in the cross-section centroid introduces a significant overall bending moment and reduces considerably the resistance of the member (Rasmussen and Hancock 1993b). As a result, pin-ended plain channel section columns need to be checked as members subject to combined compression and bending forces (i.e. beam-columns) for a design bending moment equal to the product of the axial force and an eccentricity equal to the distance between the geometric centroid of the effective cross-section and the loading point (Rasmussen and Hancock 1993b; Becque 2008; Becque and Rasmussen 2009c, 2009d). For cold-formed stainless steel members under combined axial load and bending, Clause 3.5 in SEI/ASCE 8-02 (SEI/ASCE 8 Committee 2002) establishes the beam-column check given by Eq. (6), where $P_{u}$ is the required axial strength, $M_{u x}$ and $M_{u y}$ are the required flexural strengths with respect to centroidal axes of the effective section determined for the required axial strength alone (thus including the effect of the shift in the centroidal axis), $P_{n l}$ is the nominal axial strength according to the equations presented above, $M_{n x}$ and $M_{n y}$ are the nominal flexural strengths about the centroidal axes, $1 / \alpha_{n x}$ and $1 / \alpha_{n y}$ are the magnification factors given by Eq. (7), $\phi_{c}$ and $\phi_{b}$ are the 
resistance factors for columns and beams, respectively, $C_{m x}$ and $C_{m y}$ are equivalent uniform bending factors and $P_{E}$ is the elastic flexural buckling load of the member.

$$
\begin{gathered}
\frac{P_{u}}{\phi_{c} P_{n l}}+\frac{C_{m x} M_{u x}}{\phi_{b} M_{n x} \alpha_{n x}}+\frac{C_{m y} M_{u y}}{\phi_{b} M_{n y} \alpha_{n y}} \leq 1.0 \\
\frac{1}{\alpha_{n x}}=\frac{1}{\alpha_{n y}}=\frac{1}{1-\frac{P_{u}}{P_{E}}}
\end{gathered}
$$

135

If the design is carried out using the Effective Width Method approach, a measure of the shift in the centroidal axis to evaluate the required flexural strength $\left(M_{u x}\right.$ or $\left.M_{u y}\right)$ can be obtained as the distance between the centroids of the gross and effective cross-sections. However, the Direct Design Method approach does not provide a direct estimation of the load eccentricity to be considered in design, and thus, the shift in the centroidal axis $e$ due to local buckling in plain channel sections needs to be estimated from simplified equations such as that given by Eq. (8), recently proposed in Arrayago and Rasmussen (2020). In this equation $B$ and $D$ are the overall flange width and web height of the plain channel section, respectively, and $\lambda_{p y}$ is the slenderness of the flange element, calculated from $\lambda_{p y}=\sqrt{F_{y} / \sigma_{c r}}$, where $\sigma_{c r}$ is the critical buckling stress of the flange element. The critical buckling stress can be estimated from Eq. (9), in which $E$ is the Young's modulus, $v$ is the Poisson's ratio, $t$ is the thickness of the plain channel section and $k_{f}$ is the buckling factor, adopted as $k_{f}=0.425$ for outstand elements in pure compression.

$$
\begin{array}{ll}
\text { For } B>D / 3 \text { and } \lambda_{p y}>1.0 & e=\frac{5}{32}\left(1-\frac{1}{\lambda_{p y}}\right) B \\
\text { Otherwise } & e=0 \\
& \sigma_{c r}=\frac{k_{f} \pi^{2} E}{12\left(1-v^{2}\right)}\left(\frac{t}{B}\right)^{2}
\end{array}
$$

Using equation Eq. (2) for the global flexural buckling stress in conjunction with the DSM strength curve for local buckling given in Eq. (4) or the traditional Effective Width Method equations, suitable $\alpha, \beta_{0}, \beta_{1}, \beta_{2}$ and $\lambda_{\text {lim }}$ parameters are calibrated in this paper for cold-formed stainless steel columns from data available in the literature and based on the SEI/ASCE 8 Specification reliability requirements described in the next section. 
154 The reliability of the different buckling curves investigated in this paper is assessed following the Load and Resistance Factor Design (LRFD) procedure provided in Section F of the AISI S100-16 Specification (AISI 2016). The material variation parameters adopted for the reliability calibrations were those recently recommended by the Steel Construction Institute (SCI 2020) for stainless steel alloys, while the geometric variation parameters were extracted from Lin et al. (1990). The statistical data (i.e. mean values and coefficients of variation (COV)) for the material and geometry variability considered in this study are summarized in Table 2, in which the subscript $n$ refers to the nominal material properties. The statistical variability data considered for loads were extracted from the Commentary of AISI S100-16 (AISI 2016), and are reported in Table 3. However, it should be noted that the material variation parameters used for the reliability analyses of the revised version of the SEI/ASCE 8-21 (SEI/ASCE 8 Committee 2021) provisions, which are reported in Table 2, are considerably higher than those adopted in the reliability calibrations for the current SEI/ASCE 8-02 (SEI/ASCE 8 Committee 2002) provisions (yield overstrength factors of 1.10 for all stainless steel families). The values in Table 2 are similar to those recommended by Afshan et al. (2015), which have been used in the validation of design expressions for the Design Manual (SCI 2017) and EN 1993-1-4 (CEN 2015) in recent years, featuring yield overstrength factors of 1.30 for austenitic, 1.20 for ferritic and 1.10 for duplex stainless steels, and to the values recently reported in Arrayago et al. (2020a) from an extensive database on different types of stainless steel families and product types, which showed yield overstrength factors of $1.22,1.22$ and 1.11 for austenitic, ferritic and duplex stainless steels, respectively.

The target reliability indices used in the calibration of the current SEI/ASCE 8-02 Specification (SEI/ASCE 8 Committee 2002) were $\beta^{*}=3.0$ and $\beta^{*}=4.0$ for members and connections, respectively, which are higher than the values used in AISI S100-16 (AISI 2016) for cold-formed structural steel owing to the lack of experience and data on stainless steel structures at the time of the publication of the SEI/ASCE 802 Specification. Considering the experience and knowledge gained about the behaviour and design of stainless steel structures over the last decades, the SEI/ASCE 8 Committee agreed to reduce the target reliability indices to $\beta^{*}=2.50$ and $\beta^{*}=3.50$ for members and connections, respectively, to align them with

180 the values adopted in the AISI S100-16 Specification (AISI 2016). Hence, the target reliability index 
considered in this study was $\beta^{*}=2.50$ and a ratio of $1 / 5$ was adopted as the dead-to-live load ratio at which the reliability index should be calculated, as per Section F of the AISI S100-16 Specification. In addition, the SEI/ASCE 8 Committee also agreed to update the resistance factor prescribed in SEI/ASCE 8-02 (SEI/ASCE 8 Committee 2002) for cold-formed columns to $\phi_{c}=0.90$ when proposing the revised buckling curves for the upcoming SEI/ASCE 8-21 Specification (SEI/ASCE 8 Committee 2021) to achieve alignment with other North American Specifications including AISI S100-16 (AISI 2016), AISC 360-16 (AISC 2016) and AISC 370-21 (AISC 2021), which generally adopt resistance factors of 0.90 for both beams and columns. ASSESSMENT OF EXISTING BUCKLING CURVES AND PROPOSAL

With the aim of proposing suitable flexural buckling curves for cold-formed stainless steel columns, the applicability of buckling curves already codified in current international standards (AISC 370-21 (AISC 2021) and prEN 1993-1-4 (CEN 2020)) for open cold-formed stainless steel members has been assessed in this paper, and new curves have been derived where required. Suitable $\alpha, \beta_{0}, \beta_{1}, \beta_{2}$ and $\lambda_{\text {lim }}$ parameters for Eq. (2) have been calibrated based on experimental (Exp) and finite element (FE) databases built over the past few decades. For each buckling curve investigated, design approaches corresponding to the DSM strength curve for local buckling given in Eq. (4) and the traditional Effective Width Method equations for stainless steel specified in SEI/ASCE 8-02 (SEI/ASCE 8 Committee 2002) have been considered. The assembled database on stainless steel cold-formed columns is summarized in Table 4, in which the crosssection type, data type (Exp or FE), stainless steel grade, the range of member and local slenderness values and the number of specimens are reported.

The accuracy of the buckling curves defined in the AISC 370-21 Specification (AISC 2021) for rolled or built-up I-sections buckling about the major axis and for rolled or built-up I-sections buckling about the minor axis (denoted as Curve 1 and Curve 2 in Table 1, respectively) has been assessed using the strength data for the cold-formed stainless steel I-section, channel section and lipped channel section columns summarised in Table 4. These curves are the closest among the new AISC 370-21 (AISC 2021) buckling curves to the revised European flexural buckling curves for cold-formed open sections prEN 1993-1-4 (CEN 2020). The results corresponding to the different buckling curves considered in the analysis are reported in Table 5, Table 6 and Table 7 for cold-formed stainless steel I-section, plain channel section and lipped channel section columns, respectively. In these tables, the mean values $P_{m}$ and coefficients of variation $V_{P}$ 
of the calculated ultimate-to-predicted strength ratios $P_{u} / P_{\text {pred }}$ are reported for the different stainless steel alloy types. Results corresponding to the Direct Strength Method (DSM) and the Effective Width Method (EWM) are considered separately to assess the capability of the two approaches to account for the effect of local buckling on the strength of stainless steel columns with slender cross-section. Note that while the $P_{u} / P_{\text {pred }}$ ratios reported for I-sections and lipped channel sections correspond to column buckling checks carried out using Eqs. (1) and (2), the results provided for pin-ended plain channel section columns have been calculated using the beam-column strength equation given in Eq. (6) due to the significant effect of the shift in the centroid of the effective cross-section in such members (Becque 2008; Becque and Rasmussen 2009c, 2009d; Rasmussen and Hancock 1993b). In the case of DSM checks for plain channel columns, the shift in the centroidal axis $e$ due to local buckling has been estimated from Eq. (8), while for the checks corresponding to the EWM the load eccentricity has been directly obtained from the effective section. The corresponding reliability analyses carried out for the investigated buckling curves were based on the assumptions made in the previous section, and are also reported in Table 5, Table 6 and Table 7 for coldformed stainless steel columns, where $R_{m} / R_{n}$ is the average-to-nominal resistance ratio and $\beta$ is the reliability index calculated for a resistance factor of $\phi_{c}=0.90$.

According to the results reported in Table 5, Table 6 and Table 7, seeing the calculated reliability indices lie above the target value adopted $\beta^{*}=2.50$, flexural buckling Curve 1 is found to be appropriate for ferritic stainless steel alloys, regardless the cross-section shape and irrespective of whether the DSM or EWM is used to account for local buckling and interaction between local and global buckling. For austenitic alloys, Curve 2 provides calculated reliability indices slightly below the target value of $\beta^{*}=2.50$ when the EWM is considered for I-sections, although higher values are observed for the DSM. These results indicate that a lower buckling curve is required for austenitic cold-formed open sections, which is attributed to the considerably lower stress-strain curve characterizing austenitic stainless steel alloys in general and grade ASTM 304 in particular. Thus, a new buckling curve (denoted as Curve 3) is proposed for cold-formed austenitic stainless steel columns with open sections (see Table 8), while Curve 1 is recommended for ferritic stainless steel alloys. This proposed buckling Curve 3 provides reliability indices close to the target value $\beta^{*}$ for austenitic stainless steel I-section columns, and can be safely adopted for austenitic channel and lipped 
channel section columns, as shown in Table 5, Table 6 and Table 7. In general, the results corresponding to the DSM produce higher calculated reliability indices due to the slightly higher conservatism of the strength curve for local buckling and to the less scattered results when compared with EWM results. It is worth noticing that the revised buckling curve proposed in this paper for austenitic stainless steel cold-formed columns (Curve 3) is similar to the European buckling curve $d$ provided in the revised prEN 1993-1-4 (CEN 2020) standard for stainless steel angle and channel section columns and I-sections buckling about their minor axis, while Curve 1 , which is recommended for ferritic alloys in this paper, is slightly higher than the European buckling curve $c$ for a slenderness plateau of 0.2. Since the experimental and numerical database assembled in this paper only contained data on austenitic and ferritic stainless steel alloys, no results corresponding to duplex stainless steel have been presented. Therefore, and based on previous studies (SCI 2017; CEN 2015, 2020; Afshan et al. 2019), it is conservatively recommended that the buckling curve proposed for austenitic stainless steels also be adopted for duplex grades.

Fig. 1 and Fig. 2 present the assessment of the different buckling curves investigated (Curve 1, Curve 2 and Curve 3) against the database of ultimate strengths assembled in Table 4 for stainless steel cold-formed I-section and lipped channel columns, respectively. Since most of the experimental and numerical column strengths considered in this paper were affected by local buckling, the column strengths included in Fig. 1 and Fig. 2 have been normalised with respect to the corresponding section capacity that accounts for local buckling to partition this effect, and plotted against the associated flexural buckling slenderness $\lambda_{c}$. The section capacities have been calculated using the Direct Strength Method (DSM) $P_{D S M}$ and the Effective Width Method (EWM) $P_{E W M}$ design approaches. According to the equations introduced in the previous section, $P_{D S M}$ and $P_{E W M}$ depend on the buckling curve considered, as the local slenderness values need to be calculated at the reference global flexural buckling stress $F_{n}$ (see Eq. (5)). For simplicity, the data presented in Fig. 1 and Fig. 2 correspond to the cross-section local buckling resistances calculated for reference stresses $F_{n}$ obtained using the buckling curves proposed for each stainless steel family (Curve 1 for ferritic and Curve 3 for austenitic stainless steels). 
262 The data reported in Fig. 1 and Fig. 2 shows a considerable post-yielding capacity for most of the cold263 formed columns in the low slenderness range (i.e. when the strength is governed by the section capacity).

264 For these members with column slenderness values less than the limiting slenderness $\beta_{0}$, the post-yielding capacity of stainless steel columns can be considered through Eq. (10), which permits a linear increase in strength from the yield stress $\left(F_{y}\right)$ at $\lambda_{c}=\beta_{0}$ to the ultimate tensile strength $\left(F_{u}\right)$ at zero slenderness, following the approach proposed by Rossi and Rasmussen (2013). Similar approaches were found to be suitable for cold-formed stainless steel cross-sections and members with hollow sections in Arrayago et al. (2017a, 2017b), while a different approach providing modified imperfection factors to account for the spread of plasticity has also been recently proposed based on the Continuous Strength Method by Arrayago et al.

271 (2020b, 2020c).

$$
\text { For } \lambda_{c} \leq \beta_{0} \quad F_{n}=F_{y}+\left(1-\frac{\lambda_{c}}{\beta_{0}}\right)\left(F_{u}-F_{y}\right)
$$

272

The approach to account for the post-yielding column resistance proposed herein is defined in terms of the flexural buckling slenderness instead of including it in the local buckling DSM strength curve given in Eq. (4). It can be argued that this approach does not take into account the slenderness of the cross-section in the definition of the post-yielding resistance, which is a key parameter when defining the strength enhancement of stainless steel members due to strain hardening. However, it should be noticed that since the local buckling DSM curve does not include the post-yielding increase, the strength of long columns, which exhibit a low local buckling slenderness $\lambda_{l}$ because $F_{n}$ is low (as per Eq. (5)), remains below the elastic column buckling strength. Also, considering that the enhanced member capacity has a direct effect on the definition of the local slenderness of the cross-section through the $P_{n e}$ and $F_{n}$ parameters for the DSM and EWM approaches, respectively (see Eq. (5)), the adopted approach ensures that the reduction of the nominal column capacity due to local buckling will be greater for stocky columns with slender cross-sections, thus compensating the resistance increase obtained from Eq. (10). Curves based on Eq. (10) have been also plotted in Fig. 1 and Fig. 2, and the results demonstrate that the proposed post-yielding approach provides a good 
agreement with the available data, especially for the DSM approach. Note that the post-yielding lines plotted in Fig. 1 and Fig. 2 correspond to the average $F_{u} / F_{y}$ ratio of the specimens considered in the analysis.

\section{COLD-FORMED STAINLESS STEEL MEMBERS IN FLEXURE}

Research works on cold-formed stainless steel beams are scarcer than studies on columns. Moreover, since the majority of these investigations have been conducted on hollow section beams (Theofanous and Gardner 2010; Arrayago and Real 2016, among others), they have been limited to the cross-sectional flexural capacity of cold-formed stainless steel beams (i.e. the tests did not feature lateral-torsional buckling). Nevertheless, a few studies on unbraced stainless steel welded (Talja 1997; Japanese Institution of Architecture 1988; Wang et al. 2014) and hot-rolled (Bredenkamp et al. 1996; Klopper and Laubscher 2006) I-section beams can be found in the literature, as well as experimental (Niu et al. 2015a) and numerical (Niu et al. 2015b) studies on unbraced cold-formed I-section beams formed from two back-to-back channels and showing failure modes including the interaction of lateral-torsional and local buckling, and on unbraced cold-formed lipped channel beams affected by lateral-torsional and distortional buckling (Niu et al. 2014a, 2014b). More recently, Anwar-Us-Saadata and Ashraf (2018) investigated the extension of the Continuous Strength Method to the lateral-torsional buckling of stainless steel I-section beams through numerical simulations. Although limited, the available database on unbraced cold-formed stainless steel beams has been significantly extended since the current version of the SEI/ASCE 8-02 Specification (SEI/ASCE 8 Committee 2002) was published, and these data are used herein to revise the provisions for cold-formed members in flexure.

This section presents the derivation of the new lateral-torsional buckling curves for cold-formed stainless steel unbraced beams included in the revised SEI/ASCE 8-21 Specification (SEI/ASCE 8 Committee 2021) based on the beam curves codified in current international standards. The calibration of new lateral-torsional buckling curves uses experimental and numerical data available in the literature, and are proposed in terms of accuracy and reliability considerations. To achieve a more consistent reliability level between the DSM and EWM approaches to account for the interaction with local buckling, a new DSM strength curve for local buckling in flexure is also proposed. Finally, expressions to estimate the unbraced length limit for closedbox beams and a proposal for determining the inelastic buckling strength of stainless steel beams are also developed. 
314 Following the explicit approach assumed for stainless steel columns in the revised SEI/ASCE 8-21

315 Specification (SEI/ASCE 8 Committee 2021), the SEI/ASCE 8 Committee decided to adopt the same 316 approach for unbraced cold-formed stainless steel members subjected to lateral buckling. Accordingly, the nominal global buckling flexural strength $M_{n e}$ can be determined from Eq. (11), where $S_{f, c}$ is the elastic section modulus of the full unreduced section relative to the extreme compression fiber and $F_{n}$ is the global lateral-torsional stress, which needs to be determined from appropriate lateral-torsional buckling curves. The member capacity is limited by the first yield strength $M_{y}$, which is defined as $M_{y}=S_{f} F_{y}$, where $S_{f}$ is the elastic section modulus of the full unreduced cross-section relative to the extreme fiber for first yield. The buckling curves to determine $F_{n}$ use the same expression as for the column curves investigated in the previous section for stainless steel columns (Eq. (2)) for consistency and ease of use in design practice, but adopt different parameter values $\left(\alpha, \beta_{0}, \beta_{1}, \beta_{2}, \lambda_{\text {lim }}\right)$ and consider the lateral-torsional buckling slenderness $\lambda_{e}$ given by Eq. (12) instead of the column slenderness $\lambda_{c}$, where $F_{c r e}$ is the critical elastic lateral-torsional buckling stress. The calibration of new parameters suitable for unbraced stainless steel cold-formed beams is investigated in this paper.

$$
\begin{gathered}
M_{n e}=S_{f, c} F_{n} \leq M_{y} \\
\lambda_{e}=\sqrt{F_{y} / F_{c r e}}
\end{gathered}
$$

As for cold-formed columns, cold-formed stainless steel beams usually fail showing interaction of overall and local buckling modes, the effect of which is accounted for using the Direct Strength Method (DSM) approach in the revised SEI/ASCE 8-21 Specification (SEI/ASCE 8 Committee 2021). However, unlike for stainless steel members subjected to compression, there is currently no specific DSM curve available for cold-formed stainless steel sections in bending. Different studies investigating stainless steel beams have adopted the local buckling strength curve proposed by Becque et al. (2008) for compression also for flexural members (Niu et al. 2015a, 2015b; Arrayago et al. 2017a), although it was found to be a conservative approach because the local buckling strength curve for compression is generally lower than the strength curve for bending. Nevertheless, in the absence of a specific DSM curve for cold-formed stainless steel sections in 
bending, the DSM equation adopted in this study for local buckling in flexure (Eq. (13)) was, initially, equivalent to that used for columns (Eq. (4)), where $M_{n l}$ is the nominal flexural strength including the effect of local buckling, $M_{n e}$ is the unbraced beam resistance of the fully effective section, as per Eq. (11), and $\lambda_{l}$ is the local slenderness of the cross-section, which can be calculated from Eq. (14), where $M_{c r, l}$ is the elastic local buckling bending moment. Following the same approach adopted when developing flexural buckling curves in the previous section, suitable $\alpha, \beta_{0}, \beta_{1}, \beta_{2}$ and $\lambda_{\text {lim }}$ parameters have been calibrated in this paper for cold-formed stainless steel unbraced beams using both the DSM strength curve for local buckling given in Eq. (13) and the traditional Effective Width Method equations, and based on data available in the literature.

$$
\begin{gathered}
\frac{M_{n l}}{M_{n e}}=\left\{\begin{array}{cc}
1.0 & \text { for } \lambda_{l} \leq 0.55 \\
\lambda_{l} & -\frac{0.22}{\lambda_{l}^{2}} \quad \text { for } \lambda_{l}>0.55
\end{array}\right. \\
\lambda_{l}=\sqrt{M_{n e} / M_{c r, l}}
\end{gathered}
$$

\section{PROPOSED LATERAL-TORSIONAL BUCKLING CURVES}

The available sources of experimental and numerical ultimate strengths for unbraced cold-formed stainless steel beams subject to lateral-torsional and local buckling (Niu et al. 2015a, 2015b) are summarized in Table 9, in which the data type (Exp/FE), stainless steel grade, the range of member and local slenderness values and the number of specimens are reported. This database has been used in the assessment of different lateraltorsional buckling curves to derive the most suitable strength curves to include in the revision of the SEI/ASCE 8-21 Specification (SEI/ASCE 8 Committee 2021).

The lateral-torsional buckling curve currently provided in EN 1993-1-4 (CEN 2015) and the Design Manual (SCI 2017), applicable to all cold-formed stainless steel sections, is the European buckling curve $b$, featuring a slenderness plateau equal to $\lambda_{0, L T}=0.4$. The same curve will be also included in the revised version of the prEN 1993-1-4 (CEN 2020) standard. This lateral-torsional buckling curve has been considered in this analysis as a possible curve for the updated SEI/ASCE 8-21 Specification (referred to as "EC curve $b$ "), in addition to the lower European buckling curve $c$ (CEN 2015, 2020). The mean values $P_{m}$ and coefficients of variation $V_{P}$ of the calculated ultimate-to-predicted moment ratios $M_{u} / M_{\text {pred }}$ for these two buckling curves are reported in Table 10, Table 11 and Table 12 for austenitic, ferritic and duplex stainless steel cold-formed beams, respectively. Results are provided separately for using the Direct Strength 
Method (DSM, Eq. (13)) and the Effective Width Method (EWM) approaches to account for local buckling.

Table 10, Table 11 and Table 12 also report the results for the reliability analyses carried out, where $R_{m} / R_{n}$ is the average-to-nominal resistance ratio and $\beta$ corresponds to the calculated reliability index assuming a $\phi_{b}$-factor of 0.90 . Note that the reliability of the investigated buckling curves for cold-formed stainless steel unbraced beams has been assessed following the same procedure and using the same statistical data described in the previous section for cold-formed stainless steel members in compression. i.e. the statistical parameters associated with material, geometry and loading adopted in the analysis are those reported in Table 2 and Table 3, a target reliability index of $\beta^{*}=2.50$ and a resistance factor of $\phi_{b}=0.90$ have been selected, and a dead-to-live load ratio of 1/5 has been assumed.

According to the results reported in Table 10, Table 11 and Table 12, the calculated reliability indices corresponding to the EWM approach lie below the target value of $\beta^{*}=2.50$ for all stainless steel alloys when EC buckling curves $b$ and $c$ are considered. Although the calculated reliability indices appear to be adequate for the DSM approach, it should be noticed that this is attributed to the over-conservatism of the DSM strength curve for local buckling (Eq. (13)), which was provisionally taken as the strength curve for compression, and not to the appropriateness of the EC buckling curves $b$ and $c$. Thus, two revised lateraltorsional buckling curves (Curve 4 for austenitic and duplex alloys in Table 10 and Table 12, and Curve 5 for ferritic stainless steels in Table 11) are proposed in this paper for their incorporation in the upcoming version of the SEI/ASCE 8-21 Specification (SEI/ASCE 8 Committee 2021). The values for the $\alpha, \beta_{0}, \beta_{1}$, $\beta_{2}$ and $\lambda_{\text {lim }}$ parameters defining the new Curve 4 and Curve 5 are summarized in Table 13.

The results presented in Table 10, Table 11 and Table 12 indicate that lateral-torsional buckling Curves 4 and 5 provide accurate beam capacity predictions for austenitic/duplex and ferritic stainless steel alloys, respectively, with calculated reliability indices corresponding to the Effective Width Method marginally higher than the target value $\beta^{*}=2.50$, especially for austenitic and ferritic beams. The calculated reliability indices are considerably higher when the DSM strength curve for compression (Eq. (13)) is considered, indicating the need for calibrating a new and less conservative local buckling DSM strength curve for flexure. This is addressed in the next section of this paper. It should be noticed that although the lateral-torsional buckling Curve 5 has been found to be sufficient for the analysed duplex stainless steel beams, to achieve 
consistency with the strength curve grouping chosen for columns, Curve 4 has conservatively been allocated

391 to duplex alloys, thereby grouping duplex with austenitic stainless steel alloys.

The accuracy of the different lateral-torsional buckling curves has been assessed in Fig. 3, where the different buckling curves investigated (EC curve $b$, EC curve $c$, Curve 4 and Curve 5) are compared with the experimental and numerical beam strengths for the different stainless steel families. Since the experimental and numerical ultimate bending moments $M_{u}$ are also affected by local buckling, they have been normalized by the corresponding cross-section local buckling flexural capacities calculated using the DSM or EWM approaches $\left(M_{D S M}\right.$ or $M_{E W M}$ in the two figures) and plotted against the corresponding lateral-torsional buckling slenderness $\lambda_{e}$. As per the comparison for columns, $M_{D S M}$ and $M_{E W M}$ depend on the buckling curve considered through the reference global lateral-torsional buckling stress $F_{n}$, so the results shown in Fig. 3 correspond to the lateral buckling curve proposed for each type of stainless steel, i.e. Curve 4 for austenitic and duplex stainless steel grades and Curve 5 for ferritic grades.

\section{DSM STRENGTH CURVE FOR LOCAL BUCKLING IN FLEXURE}

According to the results presented in the previous section, the DSM strength curve for local buckling in compression preliminarily adopted for the design of beams results in significantly conservative resistance predictions when applied to stainless steel slender sections in flexure, as also reported in previous studies (Niu et al. 2015a, 2015b; Arrayago et al. 2017a, 2017b). Thus, as for columns, with the aim of ensuring uniform accuracy and reliability in the design provisions for stainless steel beams when using the DSM and the EWM approaches, the new DSM strength curve for local buckling in flexure given in Eq. (15) is proposed in this paper. The new DSM curve has been calibrated to provide similar $R_{m} / R_{n}$ values to those obtained for the EWM approach for the cold-formed stainless steel beam database assembled in this paper and the 411 different buckling curves considered.

$$
\frac{M_{n l}}{M_{n e}}= \begin{cases}1.0 & \text { for } \lambda_{l} \leq 0.667 \\ \frac{1.0}{\lambda_{l}^{0.8}}-\frac{0.20}{\lambda_{l}^{1.6}} & \text { for } \lambda_{l}>0.667\end{cases}
$$

The new local buckling DSM strength curve for flexure is presented in Fig. 4, together with the DSM strength curves for local buckling for carbon steel (AISI 2016) and stainless steel compression members (Eq. (13)), in addition to the strength curve provided in the SEI/ASCE 8-02 Specification (SEI/ASCE 8 Committee 
EWM reduction curve for low-to-intermediate local slenderness values, and tends towards the DSM strength curve for carbon steel in the high local slenderness range, which is governed by lower stress levels where stainless steel and carbon steel behave more similarly. Fig. 4 also includes the data for cold-formed stainless steel braced beams reported in Niu et al. (2015a, 2015b) for comparison.

The results for the reliability calibration of the new DSM local buckling strength curve for braced beams (i.e. cross-sectional behaviour) are presented in Table 14 (New DSM), along with the results for the EWM approach and the DSM strength curve for compression (Eq. (13)), calculated using the same statistical data and reliability analysis adopted for columns and unbraced beams. As shown in Table 14, the new local buckling DSM curve proposed for flexure (Eq. (15)) produces reliability indices considerably higher than the target value of $\beta^{*}=2.50$ for a resistance factor $\phi_{b}=0.90$ for braced beams, but the $\beta$-values are reasonably aligned with the corresponding values obtained for the EWM approach and are considerably lower than those reported for the DSM strength curve for compression (Eq. (13)). Nevertheless, it was found that when combined with beam strength curves for unbraced beams, which is the relevant situation in design, the reliability indices for the new DSM curve are closer to the target reliability index $\beta^{*}$. The assessment of the new DSM strength curve for unbraced stainless steel beams is presented in Table 10, Table 11 and Table 12, indicating that the proposed lateral-torsional buckling curves (Curve 4 for austenitic and duplex stainless steel grades and Curve 5 for ferritic grades) can be safely and accurately adopted in conjunction with the new DSM curve, achieving reliability levels that are close to the target value of $\beta^{*}=2.50$ and similar to those reported for the EWM. Fig. 5 shows the assessment of the new DSM curve with experimental and numerical strengths of unbraced beams. In the figure, the ultimate bending moment $M_{u}$ is normalized by the corresponding cross-section local buckling flexural resistance calculated with the new DSM curve,

$438 M_{\text {New DSM }}$.

\section{UNBRACED LENGTH LIMIT FOR CLOSED-BOX SECTIONS}

440 Having proposed revised lateral-torsional buckling curves for cold-formed stainless steel unbraced beams 441 with open cross-sections, a revised expression for the limiting laterally unbraced length $L_{u}$ is derived for 
(SEI/ASCE 8 Committee 2021)). For laterally unbraced closed-box section members with lengths less than

or equal to $L_{u}$, there is no need to consider global buckling effects, and the global lateral-torsional stress can be assumed to be equal to the yield stress, $F_{n}=F_{y}$. To derive an expression for $L_{u}$, the classical equation of the critical lateral-torsional buckling moment $M_{c r e}$ given in Eq. (16) is considered, in which $C_{b}$ is the moment gradient modification factor, $E$ and $G$ are the elastic and shear moduli, $J$ is the Saint-Venant torsion constant, $I_{y}$ is the minor axis moment of inertia, $L_{b}$ is the unbraced member length and $C_{w}$ is the warping coefficient. Seeing that for closed-box sections the term $G J$ generally dominates over $E C_{w}$, the critical lateral-torsional buckling moment of tubular section beams is approximately given by Eq. (17). Using the limiting slenderness values $\beta_{0}$ defined in Table 13 for stainless steel unbraced beams, and since the lateral-torsional slenderness is defined as $\lambda_{e}=\sqrt{M_{y} / M_{\text {cre }}}$, the limiting unbraced length $L_{u}$ is obtained as shown in Eq. (18), in which $\beta_{3}$ is 0.12 and 0.17 for austenitic/duplex and ferritic stainless steel alloys, respectively.

$$
\begin{gathered}
M_{\text {cre }}=C_{b} \sqrt{\frac{\pi^{2} E G J I_{y}}{L_{b}^{2}}+\frac{\pi^{4} E I_{y} E C_{w}}{L_{b}^{4}}} \\
M_{c r e} \cong \frac{C_{b} \pi}{L_{b}} \sqrt{E G J I_{y}} \\
L_{u}=\frac{\beta_{3} C_{b} \pi}{F_{y} S_{f}} \sqrt{E G J I_{y}}
\end{gathered}
$$

\section{$\underline{\text { PROPOSAL FOR INELASTIC BUCKLING }}$}

Clause F2.4.2 of the current AISI S100-16 Specification (AISI 2016) for cold-formed steel structures allows accounting for the inelastic buckling resistance of cold-formed steel beams. The Clause is based on research conducted by Shifferaw and Schafer (2012), in which it was assumed that for most common cold-formed steel sections the global slenderness required for a cold-formed steel beam to reach the plastic bending moment capacity $M_{p}$ is half of that of a hot-rolled steel beam. Note that resistance reserve due to inelastic buckling can only be accounted for in stocky beams, which occurs at the slenderness plateau of the corresponding lateral-torsional buckling curve, $\lambda_{e} \leq \beta_{0}$. The procedure adopted to derive the equivalent expression to account for inelastic buckling in cold-formed stainless steel beams is described in this section. 

steel beam based on the tangent modulus approach, which can be written in terms of the inelastic buckling stress $\sigma_{i n, b u c k}$ as per Eq. (20). The tangent modulus $E_{t}$ at any particular stress level $\sigma$ can be estimated from Eq. (21) for nonlinear materials whose stress-strain curve can be accurately represented by the RambergOsgood material model (Ramberg and Osgood 1943), including stainless steels, where $n$ is the strain hardening parameter of the material. By substituting Eq. (21) in Eq. (19), and equating the resulting equation with Eq. (20), the unbraced member length $L_{b}$ at failure can be expressed as a function of the failure stress $(\sigma)$, as per Eq. (22).

$$
\begin{gathered}
M_{u}=M_{n e}=\frac{E_{t}}{E} \frac{\pi^{2} E}{L_{b}^{2}} \sqrt{I_{y} C_{w}} \\
\frac{E_{t}}{E}=\frac{M_{u}=\sigma_{i n, b u c k} S_{f}}{1+0.002 \frac{E n}{F_{y}}\left(\frac{\sigma}{F_{y}}\right)^{n-1}} \\
L_{b}^{2}=\frac{\pi^{2} E \sqrt{I_{y} I_{w}}}{S_{f}} \frac{1}{\sigma+0.002 E n\left(\frac{\sigma}{F_{y}}\right)^{n}}
\end{gathered}
$$

472

The proposed provisions for the inelastic lateral-torsional buckling moment aim to provide a transition between the elastic bending moment capacity $M_{y}$ and the plastic bending moment capacity $M_{p}$, as shown in Fig. 6, for slenderness values ranging between the limiting slenderness $\beta_{0}$ and a fraction of thereof $c \cdot \beta_{0}$. The central issue is, therefore, to estimate the $c$-values for the most common stainless steel families and cross-section types. If the lateral-torsional buckling curves are expressed in terms of the unbraced member length $L_{b}$ instead of the lateral-torsional buckling slenderness $\lambda_{e}$, it becomes evident that the factor $c$ can be estimated as the ratio between the unbraced lengths corresponding to beam resistances equal to $M_{p}$ and $M_{y}$, i.e. $c=L_{b, M_{p}} / L_{b, M_{y}}$, which can be calculated from Eq. (22) with the appropriate stress values. While the failure stress corresponding to $M_{y}$ is direct $\left(F_{y}\right)$, a stress corresponding to a strain level of $3 \varepsilon_{y}$ has been assumed herein to represent the failure stress at $M_{p}$, where $\varepsilon_{y}=F_{y} / E$ is the yield strain. In calculating the $c \cdot \beta_{0}$ slenderness for cold-formed stainless steel beams using Eq. (22), the representative values of the basic material properties shown Table 15 were assumed for the main stainless steel families and the remaining material parameters (i.e. ultimate tensile strength $F_{u}$ and corresponding ultimate strain $\varepsilon_{u}$ ) were calculated 
from the predictive expressions proposed in Arrayago et al. (2015). Using the bilinear material model of the

Continuous Strength Method for stainless steel alloys given in the Design Manual (SCI 2017) and in prEN 1993-1-4 (CEN 2020), stress values corresponding to strains equal to $\varepsilon_{y}$ and $3 \varepsilon_{y}\left(\sigma_{\varepsilon_{y}}\right.$ and $\left.\sigma_{3 \varepsilon_{y}}\right)$ were calculated, as were the corresponding unbraced member lengths $L_{b, M_{p}}$ and $L_{b, M_{y}}$, as reported in Table 15 . AISI S100-16 (AISI 2016) equation for the inelastic buckling resistance of cold-formed steel beams- is adopted for simplicity, as per Eq. (23), with the $\beta_{4}$ and $\beta_{5}$ parameters reported in Table 15 .

$$
\begin{aligned}
& \text { For } \lambda_{e} \leq \beta_{0}\left(\text { or for } M_{c r e}>\beta_{5} M_{y}\right), \\
& \qquad M_{n e}=M_{p}-\left(M_{p}-M_{y}\right) \frac{\sqrt{M_{y} / M_{\text {cre }}}-0.23}{\beta_{4}} \leq M_{p}
\end{aligned}
$$

\section{DISCUSSION}

The strength curves derived in this paper for stainless steel columns and beams were calibrated based on the specific austenitic (ASTM grade 304), duplex (ASTM grade 2101) and ferritic (ASTM grades 430, 404 and 443 and grade $3 \mathrm{Cr} 12$ ) stainless steel grades, although their applicability has not been limited to these grades in the revised SEI/ASCE 8-21 Specification. Material characteristics that are known to influence the definition of buckling curves are the strain hardening parameter $n$, which controls the roundness of the stressstrain curve, the yield stress-to-elastic modulus ratio $e=F_{y} / E$, the ultimate strength-to-yield stress ratio $F_{u} / F_{y}$ (related to strain hardening), and ultimate tensile strain (related to ductility) (Rasmussen and Rondal 1997). Since these key material features tend to be constant within each stainless steel family, it can be assumed that the specific grades considered in this study represent closely the stainless steel families they belong to, and that the proposed strength curves can be adopted for other grades in the same family. Thus, the buckling curves included in the revised SEI/ASCE 8-21 Specification depend on stainless steel families and not on particular grades.

Likewise, it is recommended that the buckling curves proposed in this paper for cold-formed I-section beams are also prescribed for all types of cross-sections in the revised SEI/ASCE 8-21 Specification despite being calibrated for back-to-back channel beams (doubly-symmetric sections), in line with the approaches followed by the most relevant design standards for steel, including AISI S100-16 (AISI 2016), AS/NZS 4600 
(AS/NZS 2018), AISC 360 (AISC 2016) and AISC 370 (AISC 2021). These specifications identify three types of open cross-sections when referring to beam design: (i) singly- or doubly-symmetric sections bent about the symmetric axis of the cross-section, (ii) singly-symmetric sections bent about the centroidal axis perpendicular to the symmetric axis or any section bent about a non-symmetric principal axis, and (iii) pointsymmetric sections. Specifications provide different expressions for the calculation of the elastic buckling stress $F_{c r e}$ for each type of sections, but use the same buckling curve for all sections, i.e., provided $F_{c r e}$ is estimated using the appropriate expression, the buckling curve for beams is independent on the cross-section type, although it might vary from one material no another. Applying the same principle to cold-formed stainless steel beams, the same strength curve calibrated using data on doubly-symmetric sections will also be applicable to other types of sections and thus the revised SEI/ASCE 8-21 Specification prescribes the same buckling curve for beams with different section types.

Finally, it is worth mentioning that the calibration and assessment of the different proposals derived in this paper were based on databases collected from the literature, which included 308 experimental and FE results for cold-formed stainless steel columns (95 on I-sections, 76 on channel sections and 137 on lipped channel sections) and 143 experimental and FE results on I-section beams. Although the number of data points might seem limited, it covered the full ranges of member slenderness for both columns and beams $\left(\lambda_{c}=0.2-2.1\right.$ and $\lambda_{e}=0.2-2.3$ ), as shown in Tables 4 and 9 and in Figures 1, 2, 3 and 5. The database also covered an extensive range of local slenderness values relevant to cold-formed sections $\left(\lambda_{p}=0.2-2.5\right)$. Since the collated databases covered the key geometric characteristics governing the behaviour of cold-formed beams and columns, including the interaction of local and overall instabilities and the influence of material nonlinearities, the buckling curves proposed in this paper can be generally applied without further limitation.

\section{SUMMARY OF PROPOSALS}

The buckling curves proposed for cold-formed stainless steel columns and beams to be incorporated in the upcoming version of the SEI/ASCE 8-21 Specification are summarised as follows:

\section{$\underline{\text { Flexural buckling curves for cold-formed stainless steel columns }}$}

$$
\begin{array}{ll}
\text { For } \lambda_{c} \leq \beta_{0} & F_{n}=F_{y}+\left(1-\frac{\lambda_{c}}{\beta_{0}}\right)\left(F_{u}-F_{y}\right) \\
\text { For } \beta_{0}<\lambda_{c} \leq \lambda_{\text {limit }} & F_{n}=1.2\left(\beta_{1}\left(\lambda_{c}\right)^{\alpha}\right) F_{y}
\end{array}
$$




$$
\text { For } \lambda_{c}>\lambda_{\text {limit }} \quad F_{n}=\beta_{2} F_{\text {cre }}
$$

With the $\alpha, \beta_{0}, \beta_{1}, \beta_{2}$ and $\lambda_{\text {limit }}$ parameters given in Table 16 .

Lateral-torsional buckling curves for cold-formed stainless steel beams not accounting for inelastic buckling

$$
\begin{array}{ll}
\text { For } \lambda_{e} \leq \beta_{0} & F_{n}=F_{y} \\
\text { For } \beta_{0}<\lambda_{e} \leq \lambda_{\text {limit }} & F_{n}=1.2\left(\beta_{1}\left(\lambda_{e}\right)^{\alpha}\right) F_{y} \\
\text { For } \lambda_{e}>\lambda_{\text {limit }} & F_{n}=\beta_{2} F_{\text {cre }}
\end{array}
$$

With the $\alpha, \beta_{0}, \beta_{1}, \beta_{2}$ and $\lambda_{\text {limit }}$ parameters given in Table 17 .

Lateral-torsional buckling curves for cold-formed stainless steel beams permitting inelastic buckling

$$
\text { For } M_{\text {cre }}>\beta_{5} M_{y} \quad M_{n e}=M_{p}-\left(M_{p}-M_{y}\right) \frac{\sqrt{M_{y} / M_{\text {cre }}}-0.23}{\beta_{4}} \leq M_{p}
$$

With the $\beta_{4}$ and $\beta_{5}$ parameters given in Table 17 .

DSM strength curve for local buckling in flexure

$$
\frac{M_{n l}}{M_{n e}}= \begin{cases}1.0 & \text { for } \lambda_{l} \leq 0.667 \\ \frac{1.0}{\lambda_{l}^{0.8}}-\frac{0.20}{\lambda_{l}^{1.6}} & \text { for } \lambda_{l}>0.667\end{cases}
$$

$\underline{\text { Unbraced length limit for stainless steel closed-box sections }}$

$$
L_{u}=\frac{\beta_{3} C_{b} \pi}{F_{y} S_{f}} \sqrt{E G J I_{y}}
$$

With the $\beta_{3}$ parameters given in Table 17 .

\section{CONCLUSIONS}

This paper explains the derivation of new strength curves for columns and beams incorporated in the revised SEI/ASCE 8-21 Specification (SEI/ASCE 8 Committee 2021) for cold-formed stainless steel structural members. The derivation was based on experimental and numerical databases assembled from the literature on cold-formed stainless steel members with different cross-section and stainless steel types, including austenitic (ASTM grade 304), duplex (ASTM grade 2101) and ferritic (ASTM grades 430, 404 and 443, and grade $3 \mathrm{Cr} 12$ ) stainless steels. In deriving the buckling curves, the accuracy and safety of the curves recently included in equivalent international stainless steel standards such as AISC 370-21 (AISC 2021) and 
prEN 1993-1-4 (CEN 2020) were first evaluated based on reliability analyses, and new strength curves were

560 proposed when the available curves did not meet the SEI/ASCE 8 reliability requirements. The two 561 alternatives to account for the interaction of local and overall buckling included in the revised SEI/ASCE 821 Specification (SEI/ASCE 8 Committee 2021) (i.e. the Direct Strength Method and the Effective Width Method) have been considered throughout the paper. The new buckling curves proposed for stainless steel columns use the same general expression as the revised AISC 370-21 (AISC 2021) curves for stainless steel members but feature different coefficients and allow the post-yielding capacity due to strain hardening to be accounted for. For the lateral-torsional strength of cold-formed stainless steel unbraced beams, new buckling curves have been proposed, as has a new local buckling strength curve to be used with the Direct Strength Method for beams, chosen to ensure a consistent reliability of the design resistances provided by the Effective Width Method and the Direct Strength Method. Finally, equations are derived for the inelastic buckling resistance of cold-formed stainless steel beams and for the unbraced length limit for closed-box section beams. Although the new strength curves have been derived based on data on specific stainless steel grades and cross-section shapes, they may be generally adopted for all grades and cross-section types covered by the SEI/ASCE 8-21 Specification without further limitations since the database considered in their calibration covered the key geometric and material properties governing the behaviour of cold-formed beams and columns of each family of alloy.

\section{DATA AVAILABILITY STATEMENT}

Some or all data, models, or code used during the study were provided by a third party: experimental and numerical data. These materials may be accessed from the original publications referenced in the paper.

\section{ACKNOWLEDGEMENTS}

580 Funding for this investigation was received from the European Union's Horizon 2020 Research and

581 Innovation Programme under the Marie Sklodowska-Curie Grant Agreement No. 842395 (Project 582 NewGeneSS). 
Afshan, S., O. Zhao and L. Gardner. 2019. "Standardised material properties for numerical parametric studies of stainless steel structures and buckling curves for tubular columns.” J. Constr. Steel Res. 152, 2-11.

Afshan, S., P. Francis, N. R. Baddoo and L. Gardner. 2015. "Reliability analysis of structural stainless steel design provisions." J. Constr. Steel Res. 114, 293-304.

AISC (American Institute of Steel Construction). 2016. Specification for Structural Steel Buildings. ANSI/AISC 360. Illinois, USA: AISC.

AISC (American Institute of Steel Construction). 2021. Specification for Structural Stainless Steel Buildings. ANSI/AISC 370. Illinois, USA: AISC.

AISI (American Iron and Steel Institute). 1968. Specification for the design of light gage cold-formed stainless steel structural members. New York, USA: AISI.

AISI (American Iron and Steel Institute). 2016. North American Specification for the Design of Cold-Formed Steel Structural Members. AISC S100. Illinois, USA: AISI.

Anwar-Us-Saadata, M. and M. Ashraf. 2018. "The continuous strength method for lateral-torsional buckling of stainless steel I-beams.” Thin-Walled Struct. 130, 148-160.

Arrayago, I. and E. Real. 2016. "Experimental study on ferritic stainless steel simply supported and continuous beams.” J. Constr. Steel Res. 119, 50-62.

600

Arrayago, I. and K. J. R. Rasmussen. 2020. "The shift of the effective centroid in plain channel section columns.” Research Report R966. School of Civil Engineering, The University of Sydney. Sydney, Australia.

Arrayago, I., E. Real and E. Mirambell. 2016. "Experimental study on ferritic stainless steel RHS and SHS beam-columns." Thin-Walled Struct. 100, 93-104.

Arrayago, I., E. Real and L. Gardner. 2015. "Description of stress-strain curves for stainless steel alloys.” Mater. Des. 87, 540-552.

Arrayago, I., E. Real, E. Mirambell and L. Gardner. 2020a. "The Continuous Strength Method for the design of stainless steel hollow section." Thin-Walled Struct. 154, 106825.

Arrayago, I., E. Real, L. Gardner and E. Mirambell. 2020b. "The Continuous Strength Method for the design of stainless steel hollow section beam-columns." Submitted to Eng. Struct. (in press). 
Arrayago, I., K. J. R. Rasmussen and E. Real. 2017a. "Full slenderness range DSM approach for stainless steel hollow cross-sections." J. Constr. Steel Res. 133, 156-166.

Arrayago, I., K. J. R. Rasmussen and E. Real. 2017b. "Full slenderness range DSM approach for stainless steel hollow cross-section columns and beam-columns.” J. Constr. Steel Res. 138, 246-263.

Arrayago, I., K. J. R. Rasmussen and E. Real. 2020. "Statistical analysis of the material, geometrical and imperfection characteristics of structural stainless steels and members.” J. Constr. Steel Res. 175, 106378.

AS/NZS (Australian/New Zealand Standard). 2018. Cold-formed steel structures. AS/NZS 4600. Sydney, Australia: AS/NZS.

AS/NZS (Australian/New Zealand Standard). 2001. Cold-formed stainless steel structures. AS/NZS 4673. Sydney, Australia: AS/NZS.

Baddoo, N. R. 2008. "Stainless steel in construction: A review of research, applications, challenges and opportunities.” J. Constr. Steel Res. 64(11), 1199-1206.

Becque, J. 2008. "The Interaction of local and overall buckling of cold-formed stainless steel columns." Ph.D. thesis. The University of Sydney. Sydney, Australia.

Becque, J. and K. J. R. Rasmussen. 2009a. "Experimental investigation of the interaction of local and overall buckling of stainless steel I-columns.” J. Struct. Eng. 135(11), 1340-1348.

Becque, J. and K. J. R. Rasmussen. 2009b. "Numerical investigation of the interaction of local and overall buckling of stainless steel I-columns.” J. Struct. Eng. 135(11), 1349-1356.

Becque, J. and K. J. R. Rasmussen. 2009c. "Experimental investigation of local-overall interaction buckling of stainless steel lipped channel columns.” J. Constr. Steel Res. 65, 1677-1684.

Becque, J. and K. J. R. Rasmussen. 2009d. "A numerical investigation of local-overall interaction buckling of stainless steel lipped channel columns.” J. Constr. Steel Res. 65, 1685-1693.

Becque, J., M. Lecce and K. J. R. Rasmussen. 2008. "The Direct Strength Method for stainless steel compression members.” J. Constr. Steel Res. 64, 1231-1238.

Bredenkamp, P., H. Barnard, G. van den Berg and P. van der Merwe. 1996. "The lateral-torsional buckling strength of hot-rolled stainless steel beams.” Struct. Eng. 74 (19), 316-318.

CEN (European Committee for Standardization). 1996. Eurocode 3: Design of Steel Structures - Part 1-4: General Rules. Supplementary Rules for Stainless Steels. ENV 1993-1-4. Brussels, Belgium: CEN. 
CEN (European Committee for Standardization). 2015. Eurocode 3: Design of Steel Structures - Part 1-4: General Rules. Supplementary Rules for Stainless Steels, including amendment A1. EN 1993-1-4+A1. Brussels, Belgium: CEN.

CEN (European Committee for Standardization). 2020. Eurocode 3: Design of Steel Structures - Part 1-4: General Rules. Supplementary Rules for Stainless Steels. prEN 1993-1-4. Second draft. Brussels, Belgium: CEN.

Coetzee, J. S., G. J. van der Berg and P. van der Merwe. 1990. "The behaviour of stainless steel lipped channel axially loaded compression members." Report MD-55. Faculty of Engineering, Rand Afrikaans University.

Dobrić, J. and B. Rossi. 2020. "Column curves for stainless steel lipped-channel sections.” J. Struct. Eng. 146(10): 04020221.

Dobrić, J., D. Buđevac, Z. Marković and N. Gluhović. 2017. "Behaviour of stainless steel press-braked channel sections under compression.” J. Constr. Steel Res. 139, 236-253.

Euro Inox (The European Stainless Steel Development Association). 1994. Design Manual for Structural Stainless Steel. First Edition. Belgium.

Fan, S., F. Liu, B. Zheng, G. Shu and Y. Tao. 2014. "Experimental study on bearing capacity of stainless steel lipped C section stub columns.” Thin-Walled Struct. 83, 70-84.

Gardner, L. 2019. "Stability and design of stainless steel structures - Review and outlook." Thin-Walled Struct. 141, 208-216.

Huang, Y. and B. Young. 2013. "Tests of pin-ended cold-formed lean duplex stainless steel columns." J. Constr. Steel Res. 82, 203-215.

Japanese Institution of Architecture. 1988. "Strength and deformation of H-shaped stainless steel beams." Journal of the Kanto Branch, Japanese Institution of Architecture.

Johnson, A. L. and G. Winter. 1966. "Behaviour of stainless steel columns and beams." J. Struct. Div. 92, $97-118$. 
Klopper, J. and R. Laubscher. 2006. "The lateral torsional buckling strength of hot-rolled 3CR12 beams." Journal of the South African Institution of Civil Engineering. J. Van. die Suid-Afrik. Inst. Van. Siviele Ing. 48(1), 8-13.

Kuwamura, H. 2003. "Local buckling of thin-walled stainless steel members." Steel Structures 3, 191-201.

Lecce, M. and K. J. R. Rasmussen. 2006. "Distortional buckling of cold-formed stainless steel sections: Experimental investigation.” J. Struct. Eng. 132(4), 497-504.

Lin, S.-H., W.-W. Yu and T. V. Galambos. 1990. "ASCE LRFD Method for Stainless Steel Structures." Proceeding of the $10^{\text {th }}$ International Specialty Conference on Cold-Formed Steel Structures. St. Louis, Missouri, USA.

Niu, S., K. J. R. Rasmussen and F. Fan. 2014a. "Distortional-global interaction buckling of stainless steel Cbeams: Part I - Experimental investigation.” J. Constr. Steel Res. 96, 127-139.

Niu, S., K. J. R. Rasmussen and F. Fan. 2014b. "Distortional-global interaction buckling of stainless steel C-beams: Part II - Numerical study and design.” J. Constr. Steel Res. 96, 40-53.

Niu, S., K. J. R. Rasmussen and F. Fan. 2015a. "Local-global interaction buckling of stainless steel I-beams. I: Experimental investigation.” J. Struct. Eng. 141(8), 04014194.

Niu, S., K. J. R. Rasmussen and F. Fan. 2015b. "Local-global interaction buckling of stainless steel I-beams. II: Numerical study and design.” J. Struct. Eng. 141(8), 04014195.

Ramberg, R. and W. R. Osgood. 1943. "Description of stress-strain curves by three parameters.” Technical Note No. 902, National Advisory Committee for Aeronautics, Washington, D.C., USA.

Rasmussen, K. J. R. and G. J. Hancock. 1993a. "Design of cold-formed stainless steel tubular members. I: Columns.” J. Struct. Eng. 119(8), 2349-2367.

Rasmussen, K. J. R. and G. J. Hancock. 1993b. "The flexural behaviour of fixed-ended channel section columns." Thin-Walled Struct. 17, 45-63.

Rasmussen, K. J. R. and J. Rondal. 1997. "Strength curves for metal columns.” J. Struct. Eng. 123 (6), 721-728.

Rhodes, J., M. Macdonald and W. McNiff. 2000. "Buckling of cold-formed stainless steel columns under concentric and eccentric loading." Fifteenth International Specialty Conference on Cold-Formed Steel Structures. St. Louis, Missouri, USA. 
Rossi, B. and K. J. R. Rasmussen. 2013. "Carrying capacity of stainless steel columns in the low slenderness range.” J. Struct. Eng. 139(6), 1088-1092.

SCI (Steel Construction Institute). 2017. Design Manual for Structural Stainless Steel. Fourth Edition. UK.

SCI (Steel Construction Institute). 2020. "Proposed material factors for ASCE 8." Technical Report. UK.

SEI/ASCE 8 Committee (American Society of Civil Engineers). 1990. Specification for the Design of ColdFormed Stainless Steel Structural Members. SEI/ASCE 8. Virginia, USA: ASCE.

SEI/ASCE 8 Committee (American Society of Civil Engineers). 2002. Specification for the Design of ColdFormed Stainless Steel Structural Members. SEI/ASCE 8. Virginia, USA: ASCE.

SEI/ASCE 8 Committee (American Society of Civil Engineers). 2021. Specification for the Design of ColdFormed Stainless Steel Structural Members. SEI/ASCE 8. Virginia, USA: ASCE.

Shifferaw, Y. and B. W. Schafer. 2012. "Inelastic bending capacity of cold-formed steel members.” J. Struct. Eng. 138(4), 468-480.

Talja, A. 1997. "Test report on welded I and CHS beams, columns and beam columns." Report to the ECSC. Technical Research Centre of Finland (VTT), Finland.

Theofanous, M. and L. Gardner. 2010. "Experimental and numerical studies of lean duplex stainless steel beams." J. Constr. Steel Res. 66, 816-825.

Wang, Y., L. Yang, B. Gao, Y. Shi and H. Yuan. 2014. "Experimental study of lateral-torsional buckling behavior of stainless steel welded I-section beams.” Int. J. Steel Struct. 14(2), 411-420.

Zhao, O., L. Gardner and B. Young. 2016. "Buckling of ferritic stainless steel members under combined axial compression and bending.” J. Constr. Steel Res. 117, 35-48. 


\section{TABLES}

Table 1. Summary of parameters defining the flexural buckling curves in the revised AISC 370-21 Specification (AISC 2021) for stainless steel columns.

\begin{tabular}{ccccccc}
\hline $\begin{array}{c}\text { Buckling } \\
\text { curve }\end{array}$ & Member type & $\alpha$ & $\beta_{0}$ & $\beta_{1}$ & $\beta_{2}$ & $\lambda_{\text {lim }}$ \\
\hline Curve 0 & Rectangular HSS & 1.38 & 0.38 & 0.50 & 0.82 & 1.8 \\
Curve 1 & $\begin{array}{c}\text { Round HSS and rolled or built-up } \\
\text { I-sections in major axis }\end{array}$ & 1.18 & 0.28 & 0.46 & 0.82 & 1.8 \\
Curve 2 & $\begin{array}{c}\text { Rolled or built-up I-sections in minor } \\
\text { axis }\end{array}$ & 1.10 & 0.24 & 0.42 & 0.75 & 1.8 \\
\hline
\end{tabular}

Table 2. Statistical variability data considered for material and geometry in reliability analyses.

\begin{tabular}{ccc}
\hline Variable & Mean & COV \\
\hline \multirow{3}{*}{ Yield stress } & Austenitic: $1.20 F_{y, n}$ & Austenitic: 0.06 \\
& Ferritic: $1.20 F_{y, n}$ & Ferritic: 0.06 \\
& Duplex: $1.10 F_{y, n}$ & Duplex: 0.05 \\
Ultimate strength & $1.10 F_{u, n}$ & 0.03 \\
Geometry & 1.00 (nominal) & 0.05 \\
\hline
\end{tabular}

Table 3. Statistical variability data considered for loads in reliability analyses.

\begin{tabular}{cccc}
\hline Variable & Mean & COV & Load factor $\gamma$ \\
\hline Dead load: $G_{m} / G_{n}$ & 1.05 & 0.10 & 1.20 \\
Live load: $Q_{m} / Q_{n}$ & 1.00 & 0.25 & 1.50 \\
\hline
\end{tabular}


Table 4. Summary of the assembled experimental data on stainless steel cold-formed columns.

\begin{tabular}{|c|c|c|c|c|c|c|}
\hline Section type & $\begin{array}{l}\text { Data } \\
\text { type }\end{array}$ & $\begin{array}{l}\text { Stainless steel } \\
\text { type/grade }\end{array}$ & $\begin{array}{c}\text { Member } \\
\text { slenderness } \\
\text { range } \lambda_{c}\end{array}$ & $\begin{array}{c}\text { Local } \\
\text { slenderness } \\
\text { range } \lambda_{l}\end{array}$ & $\begin{array}{l}\text { No. } \\
\text { data }\end{array}$ & Reference \\
\hline \multirow{4}{*}{$\begin{array}{l}\text { I-section } \\
\text { Back-to- } \\
\text { back } \\
\text { channels }\end{array}$} & $\mathrm{FE}$ & Ferritic - 3Cr12 & $0.24-1.98$ & $1.12-2.52$ & 24 & $\begin{array}{l}\text { Becque and Rasmussen } \\
(2009 \mathrm{~b})\end{array}$ \\
\hline & Exp/FE & Austenitic - 304 & $0.22-1.92$ & $1.03-2.31$ & 35 & $\begin{array}{l}\text { Becque and Rasmussen } \\
(2009 \mathrm{a}, 2009 \mathrm{~b})\end{array}$ \\
\hline & FE & Ferritic -430 & $0.23-1.85$ & $1.05-2.35$ & 24 & $\begin{array}{l}\text { Becque and Rasmussen } \\
\text { (2009b) }\end{array}$ \\
\hline & Exp & Ferritic -404 & $0.42-2.08$ & 2.13 & 12 & $\begin{array}{l}\text { Becque and Rasmussen } \\
(2009 a)\end{array}$ \\
\hline \multirow{4}{*}{$\begin{array}{l}\text { Channel } \\
\text { sections }\end{array}$} & $\mathrm{FE}$ & Ferritic - 3Cr12 & $0.26-2.07$ & $1.18-2.47$ & 24 & Becque (2008) \\
\hline & $\mathrm{FE}$ & Austenitic - 304 & $0.24-1.90$ & $1.08-2.27$ & 24 & Becque (2008) \\
\hline & $\mathrm{FE}$ & Ferritic - 430 & $0.24-1.93$ & $1.10-2.31$ & 24 & Becque (2008) \\
\hline & Exp & Austenitic -304 & 0.32 & 0.39 & 4 & Dobrić et al. (2017) \\
\hline \multirow{5}{*}{$\begin{array}{l}\text { Lipped } \\
\text { channel } \\
\text { sections }\end{array}$} & Exp/FE & Ferritic $-3 \mathrm{Cr} 12$ & $0.37-1.95$ & $1.08-2.40$ & 35 & $\begin{array}{c}\text { Becque and Rasmussen } \\
\text { (2009c, 2009d) }\end{array}$ \\
\hline & Exp/FE & Austenitic - 304 & $0.34-1.96$ & $1.12-2.45$ & 35 & $\begin{array}{l}\text { Becque and Rasmussen } \\
\text { (2009c, 2009d) }\end{array}$ \\
\hline & Exp/FE & Ferritic -430 & $0.45-1.95$ & $1.11-2.41$ & 35 & $\begin{array}{l}\text { Becque and Rasmussen } \\
\text { (2009c, 2009d) }\end{array}$ \\
\hline & Exp & Austenitic - 304 & $0.65-3.58$ & $0.22-0.27$ & 22 & Rhodes et al. (2000) \\
\hline & Exp & Austenitic - 304 & $0.18-0.33$ & $0.61-1.74$ & 10 & Fan et al. (2014) \\
\hline
\end{tabular}

Table 5. Assessment of the different buckling curves for cold-formed stainless steel I-section columns for DSM and EWM alternatives for accounting for local buckling ( $\beta$ calculated for $\left.\phi_{c}=0.90\right)$.

\begin{tabular}{cccccccc}
\hline Local buckling & & \multicolumn{3}{c}{ Austenitic stainless steel } & \multicolumn{3}{c}{ Ferritic stainless steel } \\
\cline { 2 - 8 } approach & & Curve 1 & Curve 2 & Curve 3 & Curve 1 & Curve 2 & Curve 3 \\
\hline \multirow{4}{*}{ DSM } & $P_{m}$ & 0.94 & 0.99 & 1.01 & 1.04 & 1.10 & - \\
& $V_{P}$ & 0.121 & 0.105 & 0.091 & 0.110 & 0.097 & - \\
& $R_{m} / R_{n}$ & 1.13 & 1.19 & 1.21 & 1.25 & 1.32 & - \\
& $\beta$ & 2.34 & 2.61 & 2.77 & 2.80 & 3.07 & - \\
\hline \multirow{5}{*}{ EWM } & $P_{m}$ & 0.88 & 0.93 & 0.95 & 0.97 & 1.03 & - \\
& $V_{P}$ & 0.118 & 0.103 & 0.091 & 0.107 & 0.095 & - \\
& $R_{m} / R_{n}$ & 1.06 & 1.11 & 1.14 & 1.17 & 1.23 & - \\
& $\beta$ & 2.09 & 2.36 & 2.50 & 2.54 & 2.81 & - \\
\hline
\end{tabular}


Table 6. Assessment of the different buckling curves for cold-formed stainless steel channel section columns for DSM and EWM alternatives for accounting for local buckling ( $\beta$ calculated for $\left.\phi_{c}=\phi_{b}=0.90\right)$.

\begin{tabular}{cccccccc}
\hline Local buckling & & \multicolumn{3}{c}{ Austenitic stainless steel } & \multicolumn{3}{c}{ Ferritic stainless steel } \\
\cline { 3 - 8 } approach & & Curve 1 & Curve 2 & Curve 3 & Curve 1 & Curve 2 & Curve 3 \\
\hline \multirow{4}{*}{ DSM } & $P_{m}$ & 1.08 & 1.12 & 1.15 & 1.22 & 1.27 & - \\
& $V_{P}$ & 0.122 & 0.105 & 0.093 & 0.128 & 0.113 & - \\
& $R_{m} / R_{n}$ & 1.30 & 1.35 & 1.38 & 1.47 & 1.52 & - \\
& $\beta$ & 2.89 & 3.14 & 3.28 & 3.33 & 3.57 & - \\
\hline \multirow{5}{*}{ EWM } & $P_{m}$ & 0.99 & 1.02 & 1.04 & 1.11 & 1.14 & - \\
& $V_{P}$ & 0.119 & 0.123 & 0.131 & 0.122 & 0.124 & - \\
& $R_{m} / R_{n}$ & 1.19 & 1.22 & 1.24 & 1.33 & 1.37 & - \\
& $\beta$ & 2.56 & 2.65 & 2.67 & 2.96 & 3.08 & - \\
\hline
\end{tabular}

Table 7. Assessment of the different buckling curves for cold-formed stainless steel lipped channel section columns for DSM and EWM alternatives for accounting for local buckling ( $\beta$ calculated for $\left.\phi_{c}=0.90\right)$.

\begin{tabular}{cccccccc}
\hline \multirow{2}{*}{$\begin{array}{c}\text { Local buckling } \\
\text { approach }\end{array}$} & & \multicolumn{3}{c}{ Austenitic stainless steel } & \multicolumn{3}{c}{ Ferritic stainless steel } \\
\cline { 3 - 8 } & & Curve 1 & Curve 2 & Curve 3 & Curve 1 & Curve 2 & Curve 3 \\
\hline \multirow{3}{*}{ DSM } & $P_{m}$ & 0.94 & 1.01 & 1.05 & 1.11 & 1.18 & - \\
& $V_{P}$ & 0.120 & 1.107 & 0.091 & 0.081 & 0.073 & - \\
& $R_{m} / R_{n}$ & 1.13 & 1.21 & 1.26 & 1.33 & 1.42 & - \\
& $\beta$ & 2.35 & 2.69 & 2.92 & 3.21 & 3.50 & - \\
\hline \multirow{5}{*}{ EWM } & $P_{m}$ & 0.91 & 0.97 & 1.00 & 1.01 & 1.08 & - \\
& $V_{P}$ & 0.109 & 0.110 & 0.105 & 0.121 & 0.124 & - \\
& $R_{m} / R_{n}$ & 1.10 & 1.16 & 1.21 & 1.21 & 1.29 & - \\
& $\beta$ & 2.27 & 2.50 & 2.68 & 2.60 & 2.85 & - \\
\hline
\end{tabular}

Table 8. Summary of parameters defining the proposed buckling curves for cold-formed stainless steel columns.

\begin{tabular}{ccccccc}
\hline $\begin{array}{c}\text { Buckling } \\
\text { curve }\end{array}$ & Member type and stainless steel alloy & $\alpha$ & $\beta_{0}$ & $\beta_{1}$ & $\beta_{2}$ & $\lambda_{\text {lim }}$ \\
\hline Curve 1 & $\begin{array}{c}\text { Cold-formed open sections } \\
\text { Ferritic alloys }\end{array}$ & 1.18 & 0.28 & 0.46 & 0.82 & 1.8 \\
Curve 3 & $\begin{array}{c}\text { Cold-formed open sections } \\
\text { Austenitic and Duplex alloys }\end{array}$ & 1.13 & 0.24 & 0.41 & 0.69 & 1.8 \\
\hline
\end{tabular}


Table 9. Summary of assembled experimental data on stainless steel cold-formed unbraced beams.

\begin{tabular}{ccccccc}
\hline Section type & $\begin{array}{c}\text { Data } \\
\text { type }\end{array}$ & $\begin{array}{c}\text { Stainless steel } \\
\text { type/grade }\end{array}$ & $\begin{array}{c}\text { Member } \\
\text { slenderness } \\
\text { range } \lambda_{e}\end{array}$ & $\begin{array}{c}\text { Local } \\
\text { slenderness } \\
\text { range } \lambda_{l}\end{array}$ & $\begin{array}{c}\text { No. } \\
\text { data }\end{array}$ & Reference \\
\hline & Exp & Austenitic -304 & $0.16-1.17$ & $1.05-1.69$ & 10 & Niu et al. (2015a) \\
I-sections & Exp & Ferritic -443 & $0.22-1.61$ & $0.87-1.73$ & 10 & Niu et al. (2015a) \\
Back-to-back & Exp & Duplex -2101 & $0.21-1.49$ & $0.91-1.68$ & 10 & Niu et al. (2015a) \\
channels & FE & Austenitic -304 & $0.15-2.08$ & $0.60-2.19$ & 37 & Niu et al. (2015b) \\
& FE & Ferritic -443 & $0.23-2.00$ & $0.47-2.36$ & 33 & Niu et al. (2015b) \\
& FE & Duplex -2101 & $0.21-2.35$ & $0.47-2.39$ & 43 & Niu et al. (2015b) \\
\hline
\end{tabular}

Table 10. Assessment of the different buckling curves for cold-formed austenitic stainless steel unbraced I-section beams with different alternatives for local buckling $\left(\beta\right.$ calculated for $\left.\phi_{b}=0.90\right)$.

\begin{tabular}{ccccc}
\hline $\begin{array}{c}\text { Local buckling } \\
\text { approach }\end{array}$ & & EC curve $b$ & EC curve $c$ & Curve 4 \\
\hline & $P_{m}$ & 1.04 & 1.07 & 1.14 \\
DSM & $V_{P}$ & 0.165 & 0.145 & 0.109 \\
Eq. (13) & $R_{m} / R_{n}$ & 1.24 & 1.28 & 1.37 \\
& $\beta$ & 2.49 & 2.71 & 3.17 \\
\hline & $P_{m}$ & 0.84 & 0.88 & 0.97 \\
EWM & $V_{P}$ & 0.142 & 0.128 & 0.113 \\
& $R_{m} / R_{n}$ & 1.01 & 1.06 & 1.16 \\
& $\beta$ & 1.83 & 2.05 & 2.50 \\
\hline & $P_{m}$ & 0.91 & 0.94 & 1.01 \\
New DSM & $V_{P}$ & 0.144 & 0.126 & 0.094 \\
Eq. (15) & $R_{m} / R_{n}$ & 1.09 & 1.13 & 1.21 \\
& $\beta$ & 2.09 & 2.32 & 2.75 \\
\hline
\end{tabular}

Table 11. Assessment of the different buckling curves for cold-formed ferritic stainless steel unbraced I-section beams with different alternatives for local buckling $\left(\beta\right.$ calculated for $\left.\phi_{b}=0.90\right)$.

\begin{tabular}{ccccc}
\hline $\begin{array}{c}\text { Local buckling } \\
\text { approach }\end{array}$ & EC curve $b$ & EC curve $c$ & Curve 5 \\
\hline & $P_{m}$ & 1.09 & 1.09 & 1.11 \\
DSM & $V_{P}$ & 0.114 & 0.140 & 0.130 \\
Eq. (13) & $R_{m} / R_{n}$ & 1.31 & 1.31 & 1.33 \\
& $\beta$ & 2.97 & 2.82 & 2.95 \\
\hline & $P_{m}$ & 0.87 & 0.91 & 1.01 \\
EWM & $V_{P}$ & 0.156 & 0.146 & 0.136 \\
& $R_{m} / R_{n}$ & 1.05 & 1.10 & 1.21 \\
& $\beta$ & 1.90 & 2.12 & 2.55 \\
\hline & $P_{m}$ & 0.93 & 0.96 & 0.98 \\
New DSM & $V_{P}$ & 0.135 & 0.122 & 0.115 \\
Eq. (15) & $R_{m} / R_{n}$ & 1.12 & 1.16 & 1.18 \\
& $\beta$ & 2.23 & 2.43 & 2.54 \\
\hline
\end{tabular}


Table 12. Assessment of the different buckling curves for cold-formed duplex stainless steel unbraced I-section beams with different alternatives for local buckling ( $\beta$ calculated for $\left.\phi_{b}=0.90\right)$.

\begin{tabular}{ccccc}
\hline $\begin{array}{c}\text { Local buckling } \\
\text { approach }\end{array}$ & EC curve $b$ & EC curve $c$ & Curve 4 \\
\hline & $P_{m}$ & 1.11 & 1.15 & 1.25 \\
DSM & $V_{P}$ & 0.178 & 0.157 & 0.118 \\
Eq. (13) & $R_{m} / R_{n}$ & 1.22 & 1.27 & 1.38 \\
& $\beta$ & 2.37 & 2.62 & 3.17 \\
& $P_{m}$ & 0.93 & 0.97 & 1.11 \\
EWM & $V_{P}$ & 0.140 & 0.129 & 0.126 \\
& $R_{m} / R_{n}$ & 1.02 & 1.07 & 1.22 \\
& $\beta$ & 1.88 & 2.12 & 2.63 \\
\hline & $P_{m}$ & 0.98 & 1.02 & 1.11 \\
New DSM & $V_{P}$ & 0.148 & 0.134 & 0.103 \\
Eq. (15) & $R_{m} / R_{n}$ & 1.08 & 1.12 & 1.22 \\
& $\beta$ & 2.07 & 2.27 & 2.77 \\
\hline
\end{tabular}

Table 13. Summary of parameters defining the proposed buckling curves for cold-formed stainless steel unbraced beams.

\begin{tabular}{ccccccc}
\hline $\begin{array}{c}\text { Buckling } \\
\text { curve }\end{array}$ & Member type & $\alpha$ & $\beta_{0}$ & $\beta_{1}$ & $\beta_{2}$ & $\lambda_{\text {lim }}$ \\
\hline Curve 4 & $\begin{array}{c}\text { Cold-formed open section beams } \\
\text { Austenitic and Duplex alloys }\end{array}$ & 1.44 & 0.35 & 0.44 & 0.61 & 1.6 \\
Curve 5 & $\begin{array}{c}\text { Cold-formed open section beams } \\
\text { Ferritic alloys }\end{array}$ & 1.55 & 0.41 & 0.49 & 0.70 & 1.6 \\
\hline
\end{tabular}

Table 14. Assessment of the different local buckling approaches for cold-formed stainless steel braced I-section beams -cross-section behaviour- $\left(\beta\right.$ calculated for $\left.\phi_{b}=0.90\right)$.

\begin{tabular}{ccccc}
\hline $\begin{array}{c}\text { Local buckling } \\
\text { approach }\end{array}$ & Austenitic & Ferritic & Duplex \\
\hline & $P_{m}$ & 1.41 & 1.41 & 1.60 \\
DSM & $V_{P}$ & 0.044 & 0.050 & 0.036 \\
Eq. (13) & $R_{m} / R_{n}$ & 1.70 & 1.69 & 1.76 \\
& $\beta$ & 4.42 & 4.38 & 4.66 \\
\hline & $P_{m}$ & 1.09 & 1.11 & 1.22 \\
EWM & $V_{P}$ & 0.054 & 0.050 & 0.050 \\
& $R_{m} / R_{n}$ & 1.31 & 1.34 & 1.35 \\
& $\beta$ & 3.25 & 3.34 & 3.41 \\
\hline & $P_{m}$ & 1.20 & 1.19 & 1.35 \\
New DSM & $V_{P}$ & 0.037 & 0.022 & 0.018 \\
Eq. (15) & $R_{m} / R_{n}$ & 1.44 & 1.43 & 1.49 \\
& $\beta$ & 3.71 & 3.71 & 3.94 \\
\hline
\end{tabular}


Table 15. Summary of key parameters for inelastic buckling in stainless steel cold-formed beams.

\begin{tabular}{ccccccccc}
\hline $\begin{array}{c}\text { Stainless } \\
\text { steel type }\end{array}$ & $\begin{array}{c}E \\
{[\mathrm{GPa}]}\end{array}$ & $\begin{array}{c}F_{y}\left(\sigma_{\varepsilon_{y}}\right) \\
{[\mathrm{MPa}]}\end{array}$ & $n$ & $\begin{array}{c}\sigma_{3 \varepsilon_{y}} \\
{[\mathrm{MPa}]}\end{array}$ & $c=L_{b, M_{p}} / L_{b, M_{y}}$ & $c \cdot \beta_{0}$ & $\beta_{4}$ & $\beta_{5}$ \\
\hline Austenitic & 200 & 380 & 7 & 405.2 & 0.81 & 0.33 & 0.12 & 8.16 \\
Ferritic & 200 & 430 & 14 & 443.8 & 0.81 & 0.32 & 0.18 & 5.95 \\
Duplex & 200 & 520 & 8 & 559.2 & 0.77 & 0.31 & 0.12 & 8.16 \\
\hline
\end{tabular}

Table 16. Parameters defining the proposed buckling curves for cold-formed stainless steel columns.

\begin{tabular}{cccccc} 
Member type and stainless steel alloy & $\alpha$ & $\beta_{0}$ & $\beta_{1}$ & $\beta_{2}$ & $\lambda_{\text {limit }}$ \\
\hline $\begin{array}{c}\text { Cold-formed open sections } \\
\text { Austenitic and Duplex }\end{array}$ & 1.13 & 0.24 & 0.41 & 0.69 & 1.8 \\
$\begin{array}{c}\text { Cold-formed open sections } \\
\text { Ferritic }\end{array}$ & 1.18 & 0.28 & 0.46 & 0.82 & 1.8 \\
\hline
\end{tabular}

Table 17. Parameters defining the proposed buckling curves for cold-formed stainless steel unbraced beams.

\begin{tabular}{ccccccccc}
\hline $\begin{array}{c}\text { Member type and stainless steel } \\
\text { alloy }\end{array}$ & $\alpha$ & $\beta_{0}$ & $\beta_{1}$ & $\beta_{2}$ & $\lambda_{\text {limit }}$ & $\beta_{3}$ & $\beta_{4}$ & $\beta_{5}$ \\
\hline $\begin{array}{c}\text { Cold-formed open section beams } \\
\text { Austenitic and Duplex alloys }\end{array}$ & 1.44 & 0.35 & 0.44 & 0.61 & 1.6 & 0.12 & 0.12 & 8.16 \\
$\begin{array}{c}\text { Cold-formed open section beams } \\
\text { Ferritic alloys }\end{array}$ & 1.55 & 0.41 & 0.49 & 0.70 & 1.6 & 0.17 & 0.18 & 5.95 \\
\hline
\end{tabular}




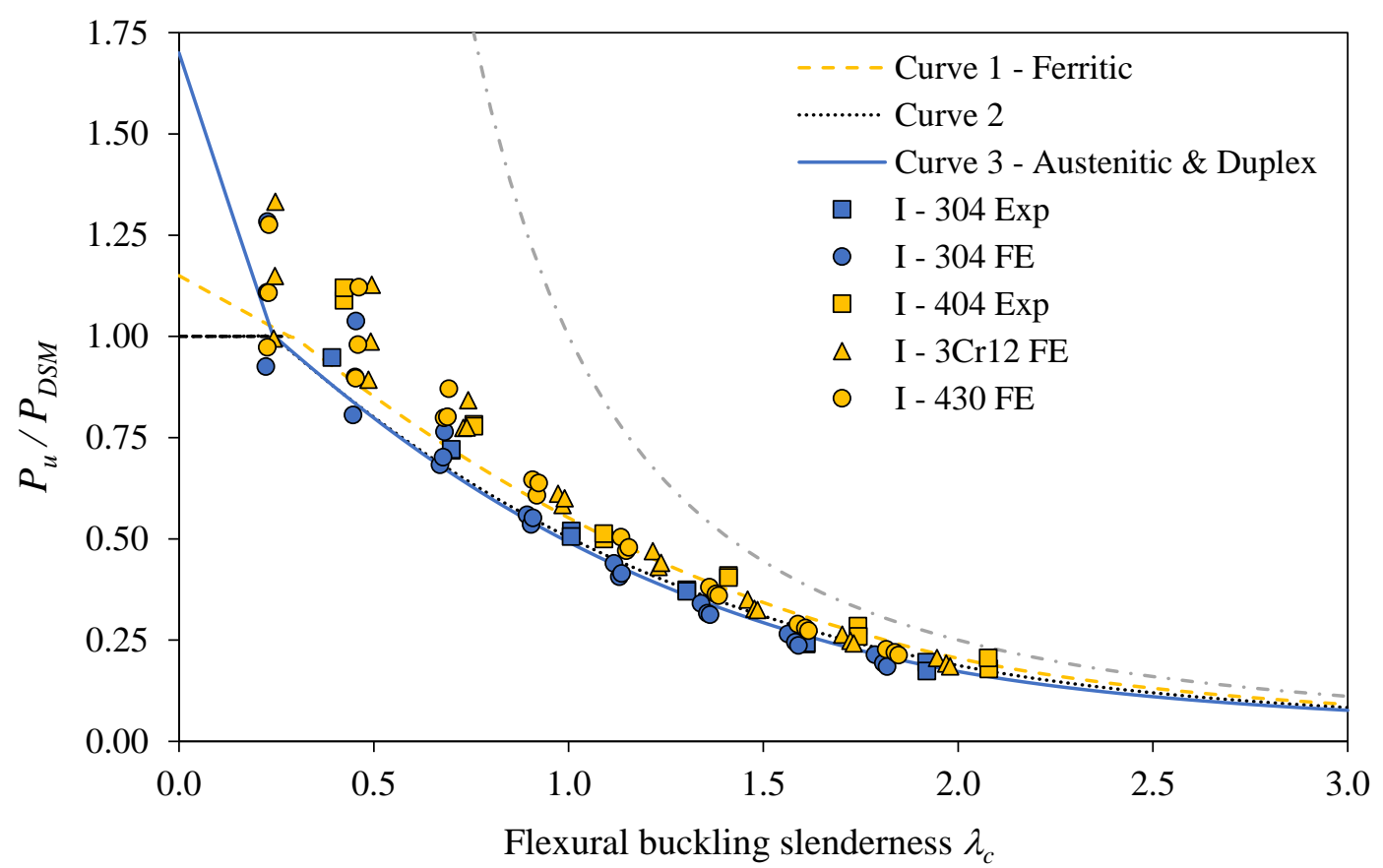

(a)

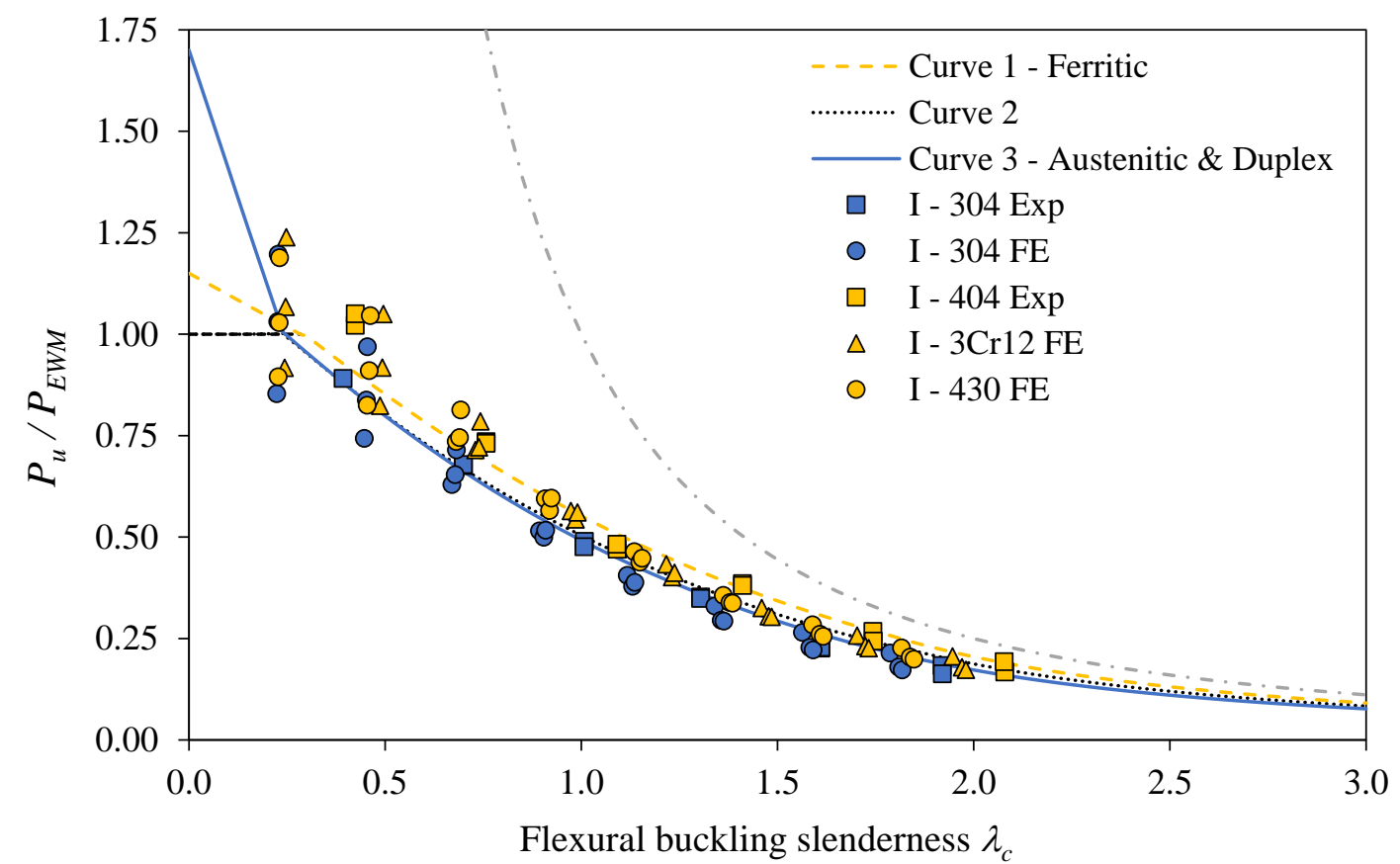

(b)

Fig. 1. Assessment of different buckling curves for stainless steel cold-formed I-section columns with (a) DSM for local buckling; (b) EWM for local buckling. 


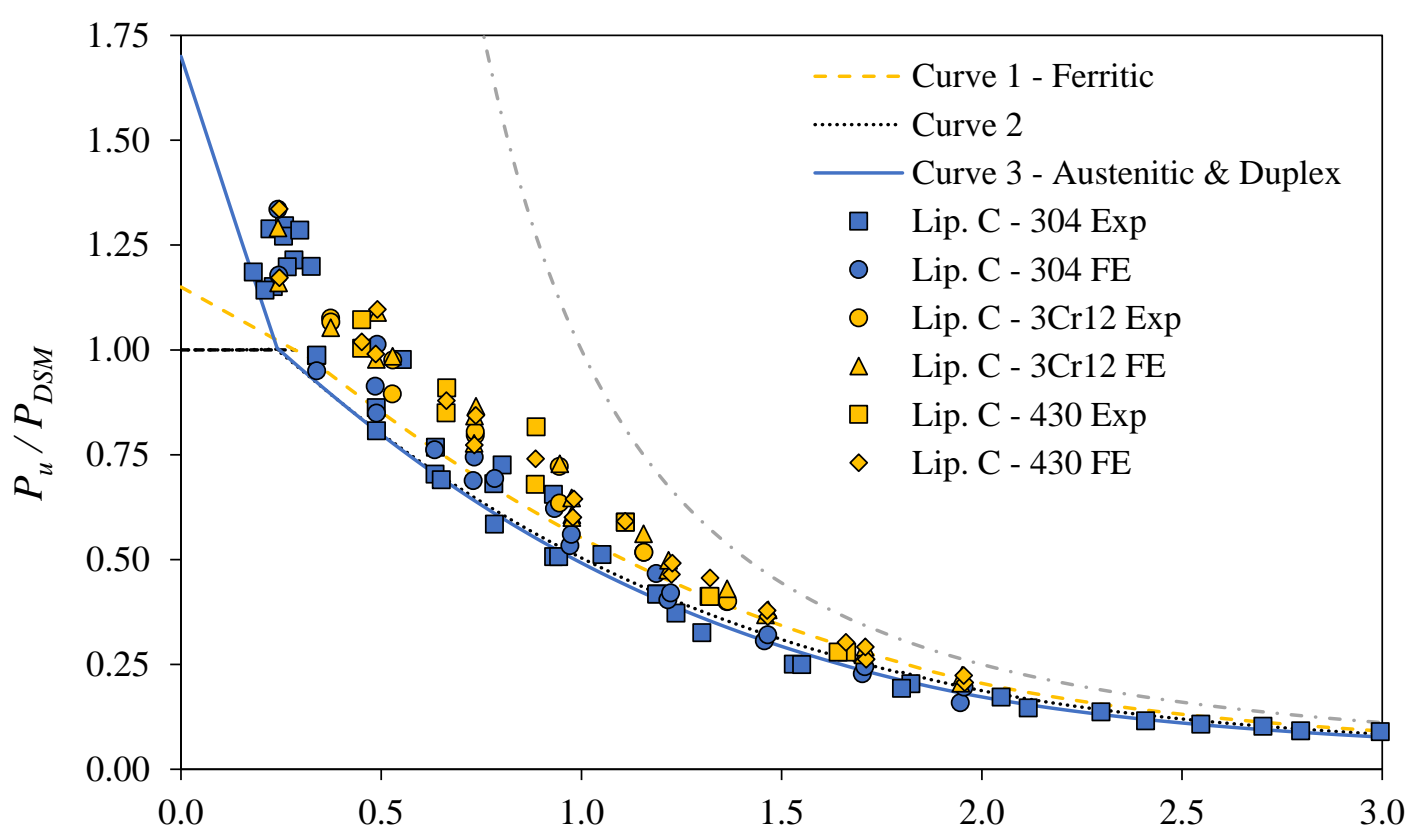

(a)

Flexural buckling slenderness $\lambda_{c}$

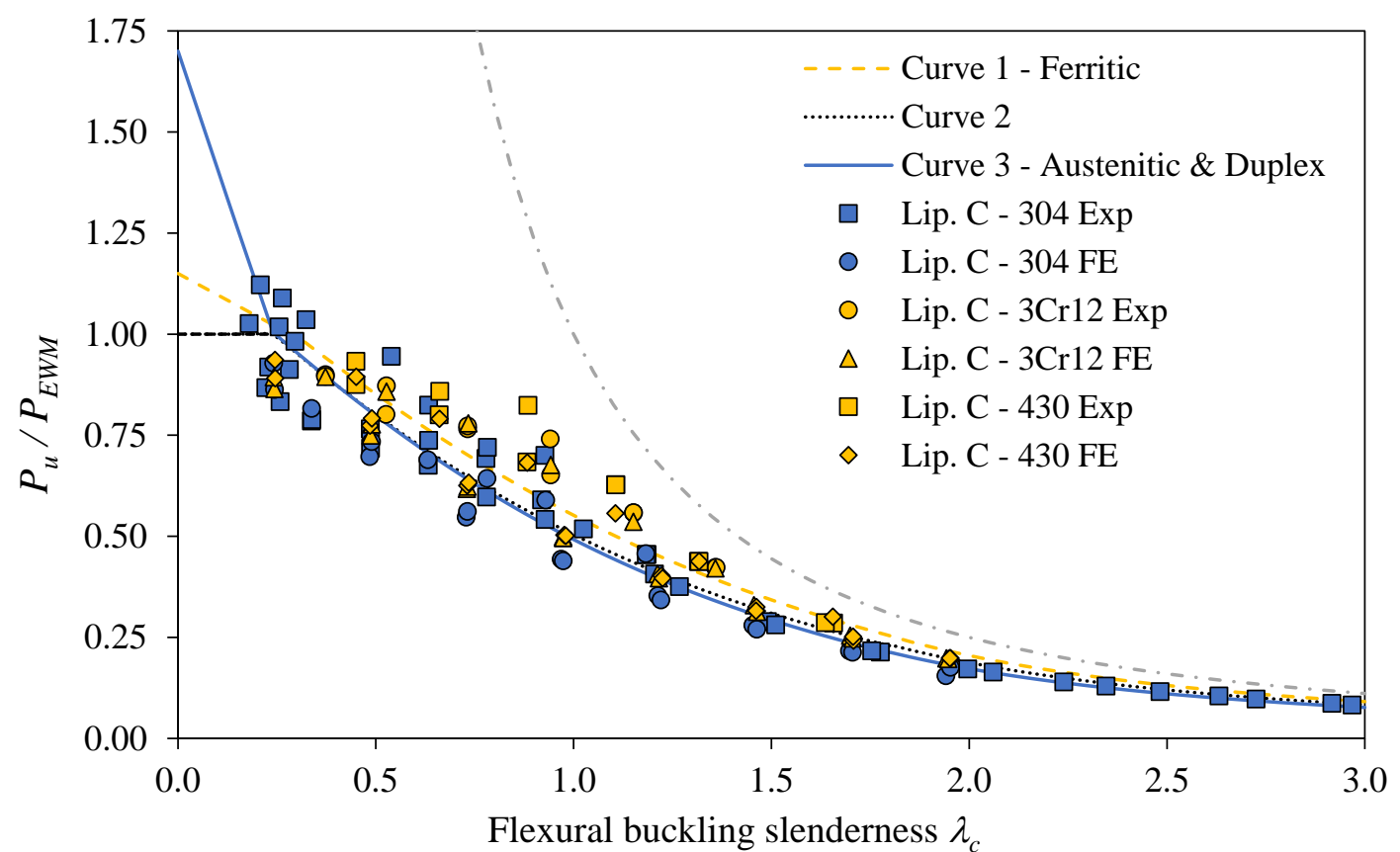

(b)

Fig. 2. Assessment of different buckling curves for stainless steel cold-formed lipped channel columns with (a) DSM for local buckling; (b) EWM for local buckling. 


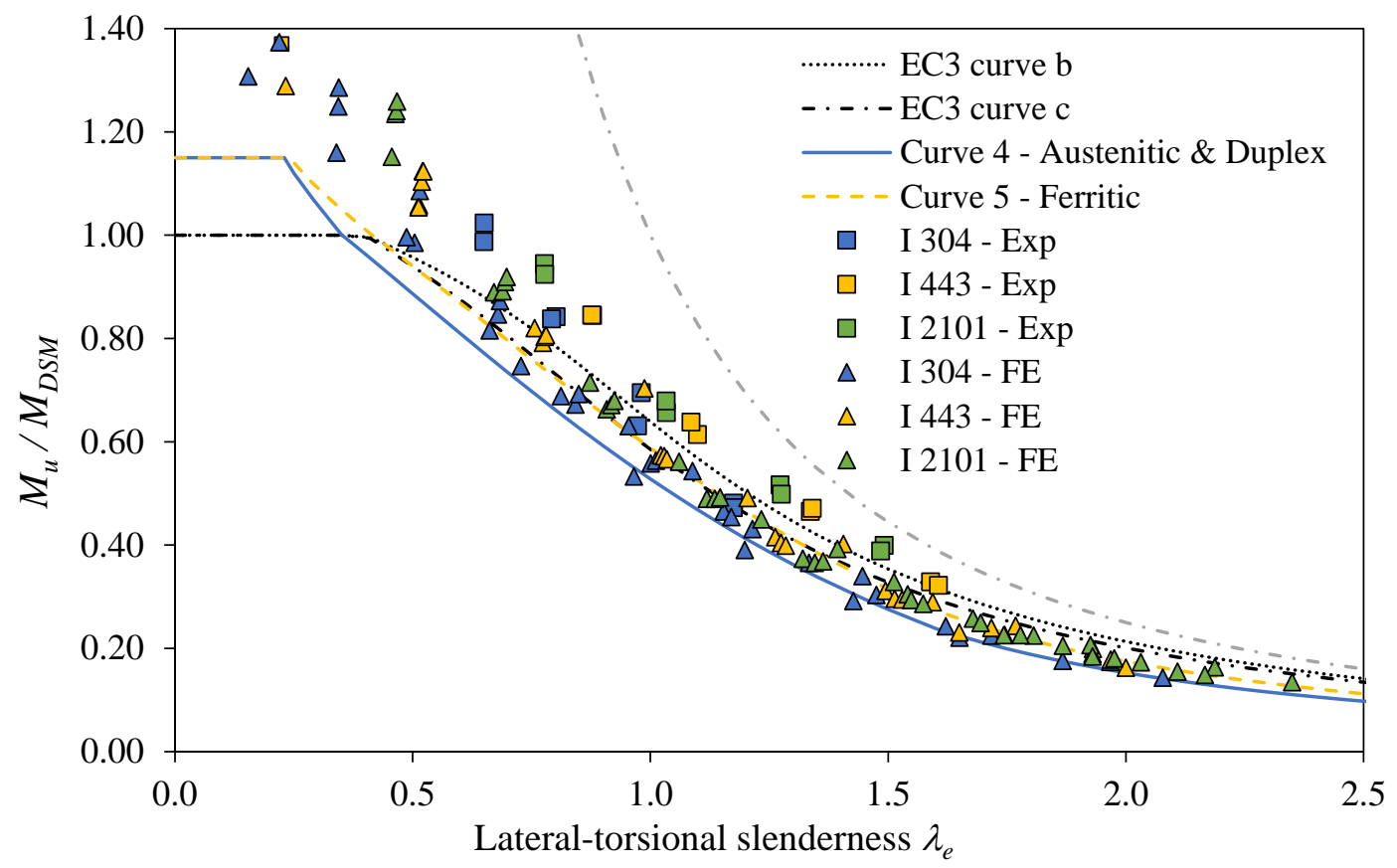

(a)

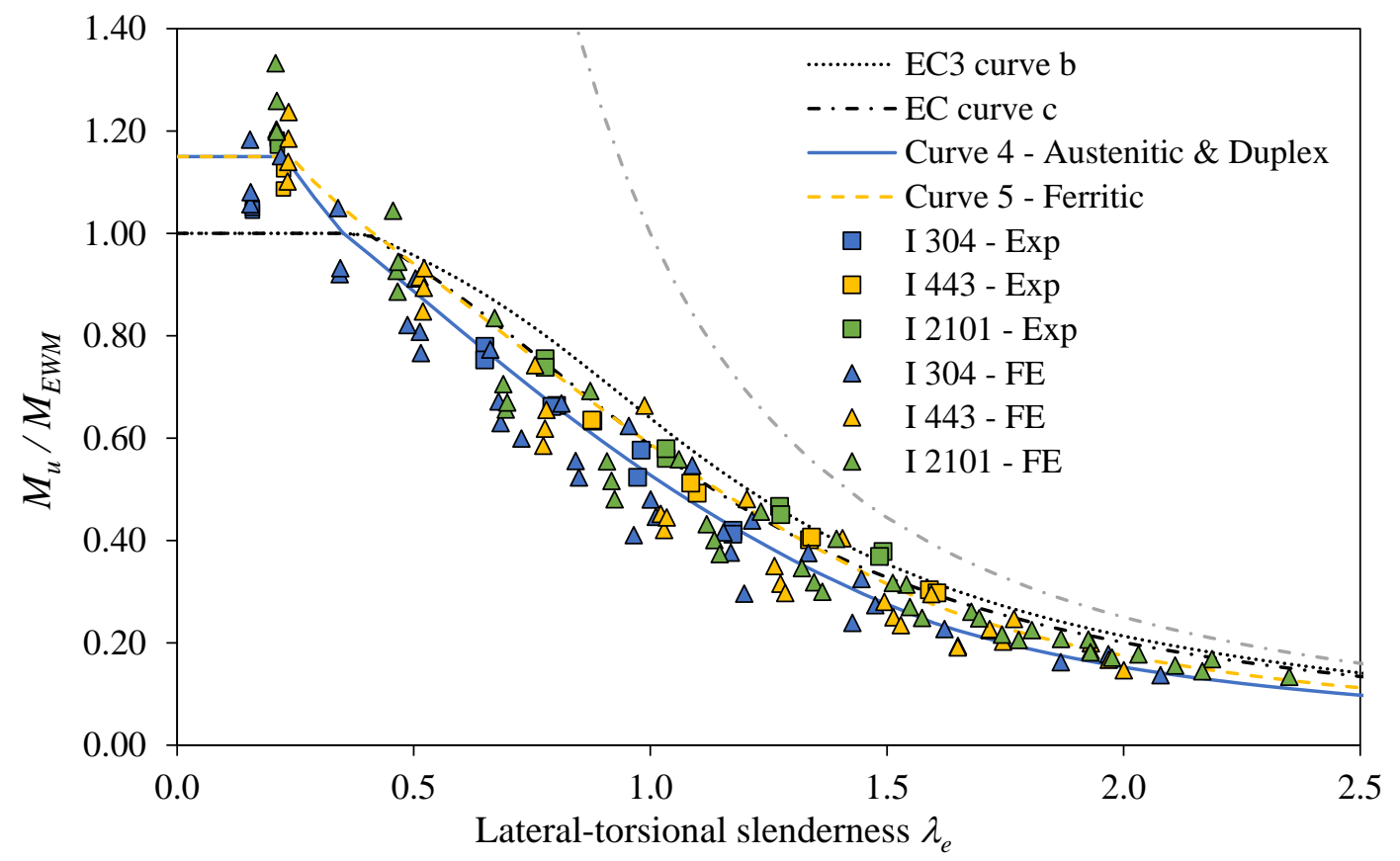

Fig. 3. Assessment of proposed buckling curves against data for stainless steel cold-formed unbraced beams with (a) DSM for local buckling; (b) EWM for local buckling. 


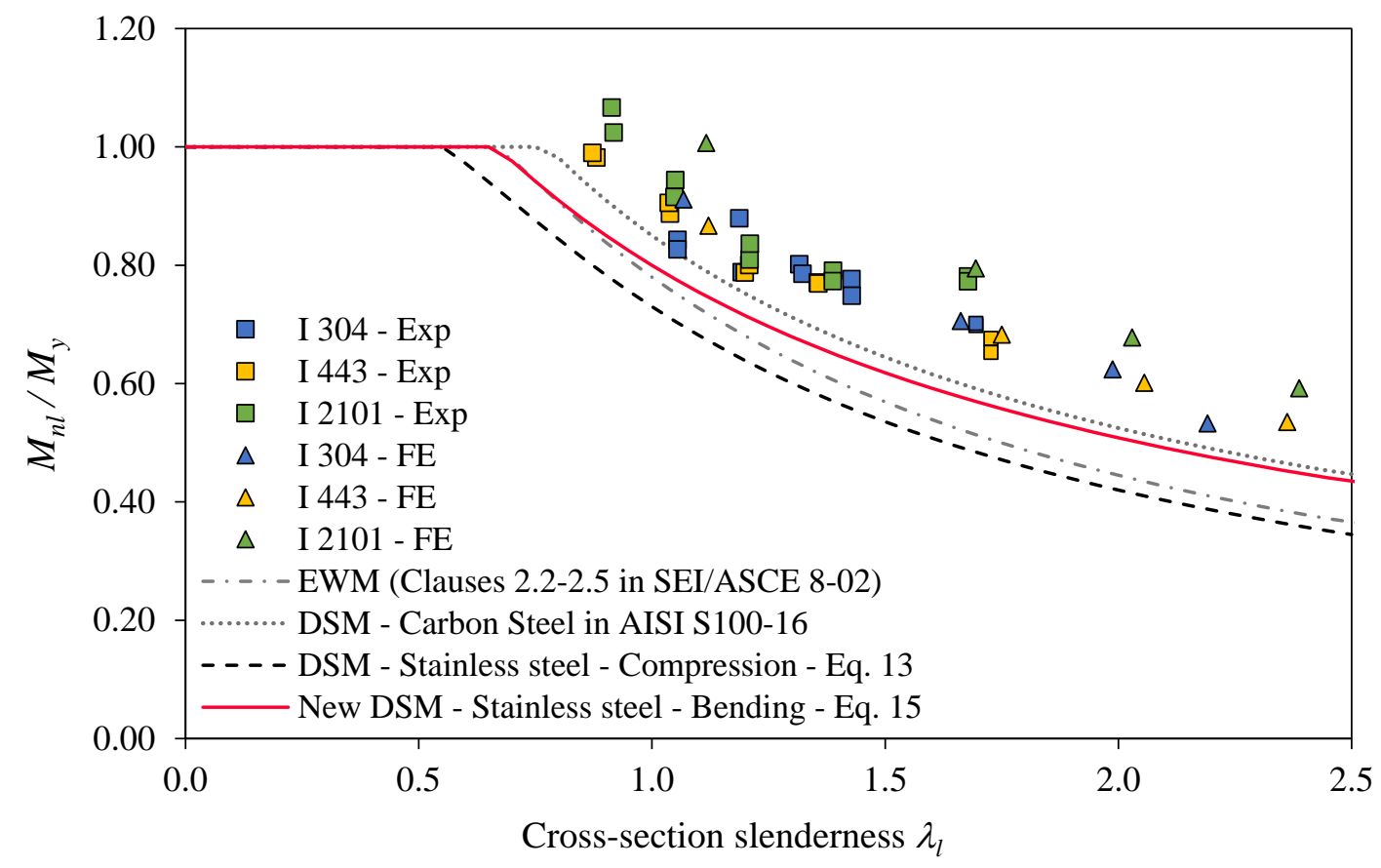

Fig. 4. Comparison of the new DSM strength curve proposed for local buckling in flexure with other reduction curves.

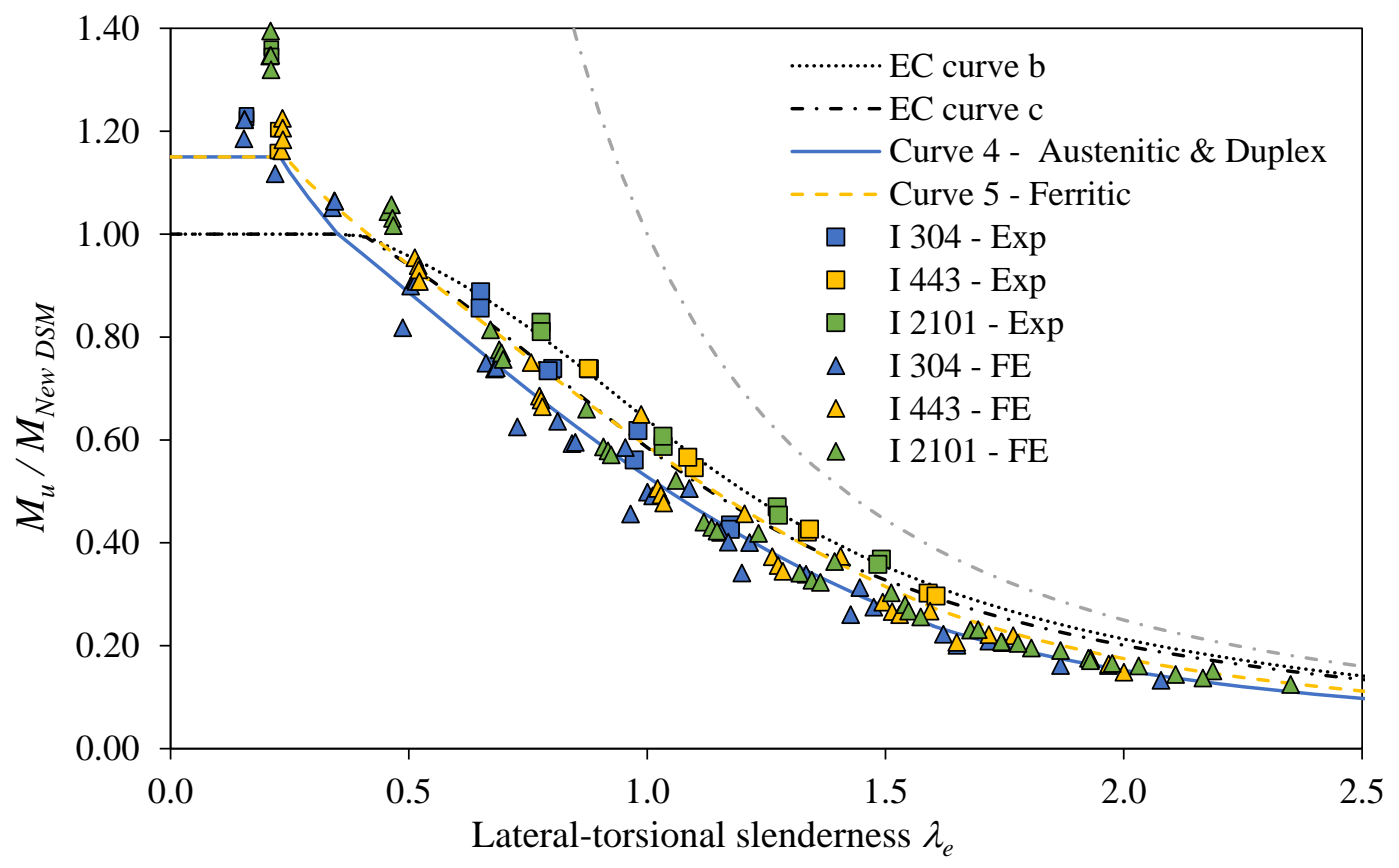

Fig. 5. Assessment of proposed buckling curves against data for stainless steel cold-formed unbraced beams with the new DSM strength curve for local buckling in flexure. 


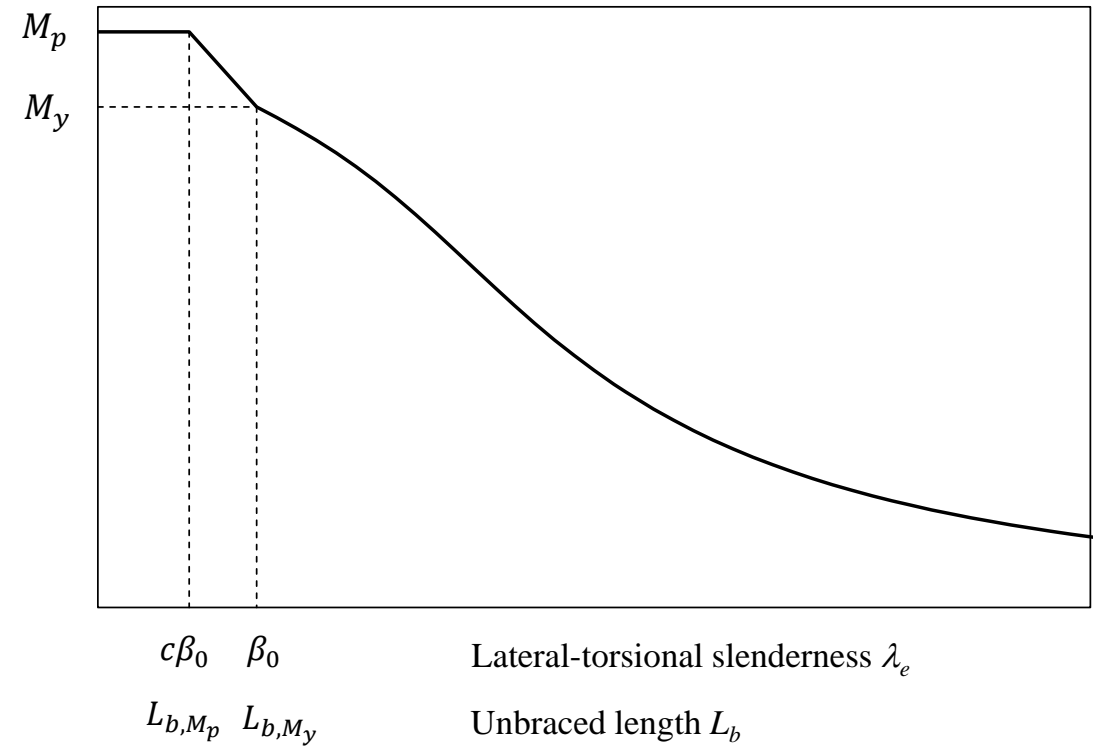

Fig. 6. Definition of key slenderness limits for lateral-torsional inelastic buckling in stainless steel beams. 